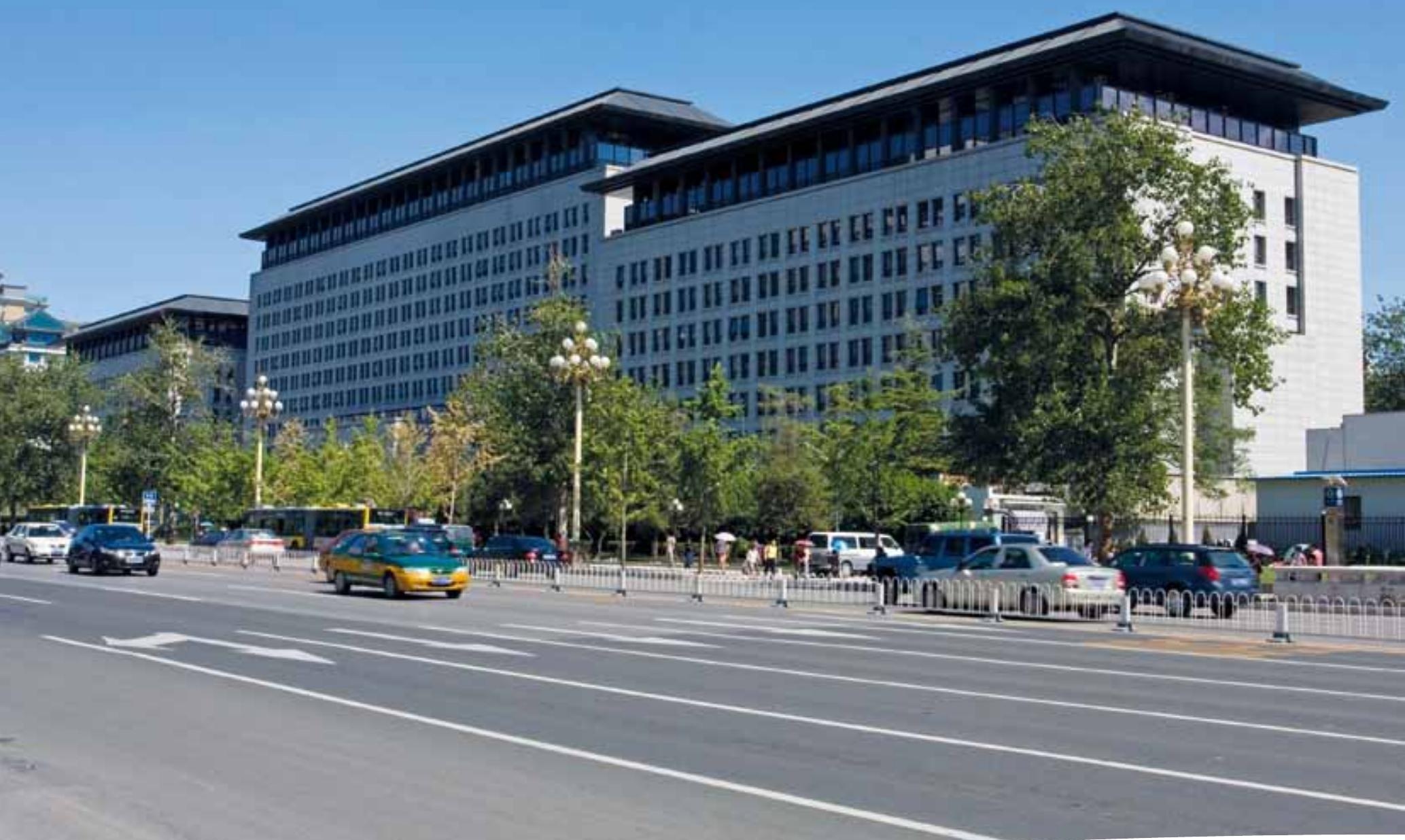

\title{
Analysis of approvals for Chinese companies to invest in Africa's mining, agriculture and forestry sectors
}

Huang Wenbin

Andreas Wilkes

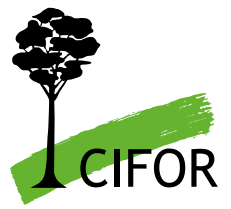



Working Paper 81

\section{Analysis of approvals for Chinese companies to invest in Africa's mining, agriculture and forestry sectors}

Huang Wenbin

World Agroforestry Centre, China and East Asia Node, Beijing

Andreas Wilkes

World Agroforestry Centre, China and East Asia Node, Beijing 
Working Paper 81

○ 2011 Center for International Forestry Research

All rights reserved

Huang, W. and Wilkes, A. 2011 Analysis of approvals for Chinese companies to invest in Africa's mining, agriculture and forestry sectors. Working Paper 81. CIFOR, Bogor, Indonesia.

Cover photo by lain Ding

Ministry of Commerce (MOFCOM) complex on Chang'an Avenue in Beijing. MOFCOM serves Chinese business interests both at home and overseas and its support is behind many of China's recent international business expansion endeavors.

CIFOR

Jl. CIFOR, Situ Gede

Bogor Barat 16115

Indonesia

$\mathrm{T}+62(251) 8622-622$

$\mathrm{F}+62(251) 8622-100$

E cifor@cgiar.org

www.cifor.org

Any views expressed in this publication are those of the authors. They do not necessarily represent the views of CIFOR, the authors' institutions or the financial sponsors of this publication. 


\section{Table of contents}

Abbreviations $\quad$ v

Acknowledgements $\quad v$

Summary

1 Introduction 1

2 Approvals for investment by Chinese companies in Africa 2

2.1 Trends in investment approvals $\quad 2$

2.2 Investment destinations of approvals for Africa 2

2.3 Intended investments by type and sector 3

3 Approvals for Chinese companies investing in Africa's mining, forestry and agriculture sectors 3

3.1 Overview 3

3.2 Mining investment approvals in Africa $\quad 4$

3.3 Forestry investment approvals in Africa $\quad 4$

3.4 Agricultural investment approvals in Africa 5

4 Chinese mining, forestry and agriculture investment approvals in the eco-regions 6

4.1 Overview 6

4.2 Mining investment approvals in the eco-regions 6

4.3 Forestry investment approvals in the eco-regions 6

$\begin{array}{ll}4.4 \text { Agricultural investment approvals in the eco-regions } & 7\end{array}$

5 Chinese companies' merger and acquisition activities in Africa $r$

6 Discussion 9

$\begin{array}{llr}7 & \text { References } & 10\end{array}$

Annexes
1 List of Chinese companies approved to invest in African mining, forestry and agriculture

2 Major recent Chinese outward merger and acquisition events 23 


\section{List of tables and figures}

\section{Table}

1 Sectoral distribution of Chinese mining investment approvals

\section{Figures}

1 Number of companies receiving approval to invest in Africa (1988-2010) 2

2 Top 10 Chinese intended investment destinations in Africa 2

3 Composition of investment approvals in Africa by economic sector (1988-2010) 3

4 Major Chinese mining investment approval destinations in Africa 4

5 Sectoral distribution of Chinese mining investment approvals 4

6 Top five destinations in Africa for intended forestry investments by Chinese companies 5

7 Sectoral distribution of Chinese forestry investment approvals 5

8 Major Chinese agriculture investment approval destinations in Africa 6

9 Sectoral distribution of Chinese agriculture investment approvals 6

10 Major Chinese mining investment destinations in the eco-regions $\quad 7$

11 Sectoral distribution of Chinese mining investment approvals in the eco-region $\quad 7$

12 Major Chinese forestry investment destinations in the eco-regions $\quad 7$

13 Sectoral distribution of Chinese forestry investment in the eco-regions $\quad 7$

14 Major Chinese agricultural investment destinations in the eco-regions $\quad 8$

15 Chinese overseas merger and acquisition events (2003 to mid-2010) 8

16 Sectoral composition of Chinese overseas merger and acquisitions by number of M\&A events (2003 to mid-2010) 


\section{Abbreviations}

BMZ Bundesministerium für wirtschaftliche Zusammenarbeit und Entwicklung (Federal Ministry for Economic Cooperation and Development), Germany

CIFOR Center for International Forestry Research

DRC Democratic Republic of Congo

GIZ Gesellschaft für Internationale Zusammenarbeit, Germany

ICRAF World Agroforestry Centre

M\&A Mergers and acquisitions

MOFCOM Ministry of Commerce, PR China

MOFTEC Ministry of Foreign Trade and Economic Cooperation, PR China

NPC National Planning Commission

OFDI Outward Foreign Direct Investment

\section{Acknowledgements}

This working paper is a product of the project 'Chinese Trade and Investment in Africa: Assessing and Governing Trade-offs to National Economies, Local Livelihoods and Forest Ecosystems'. The project has been supported by a grant from the German Federal Ministry for Economic Cooperation and Development (BMZ) through the Gesellschaft für Internationale Zusammenarbeit (GIZ) to CIFOR, and is implemented by CIFOR, the World Agroforestry Centre and the University of Leipzig. Research for this working paper was conducted by the World Agroforestry Centre's China and East Asia Node Beijing Office. 


\section{Summary}

The impacts of Chinese investment in and trade with Africa have become the subject of much speculation. CIFOR's 'Chinese trade and investment in Africa' project seeks to understand the impacts of China's role in shifting global trade flows and investment patterns on forests in 2 African eco-regions, the Congo Basin and the southern African woodlands, with a focus on sectors with potential direct impacts on forests: mining, forestry and agriculture.

The lack of a comprehensive database of Chinese investments in Africa makes it difficult to build a picture and analyse trends and patterns. The analysis in this working paper draws on a database (spanning 1983 to 2010) of approvals by the Ministry of Commerce of the People's Republic of China (MOFCOM) for Chinese companies to engage in overseas investments. Records in the database indicate the companies' intent to invest overseas, but do not record actual investments that were completed. Additional sources are used to characterise trends in Chinese merger and acquisition activities in the sectors of concern in Africa.

The database contains 1346 records of approvals for Chinese companies to invest in Africa from 1988 to 2010 , representing $8.47 \%$ of all approvals for overseas investment awarded to Chinese companies. Before 2002, fewer than 10 approvals were made per year. After 2002, approvals grew at an annual average rate of $250 \%$, reaching 388 in 2010 . Of these, 278 approvals were for the mining, forestry and agriculture sectors, of which 128 (44\%) were in the 2 eco-regions of interest to the CIFOR project.

In the mining sector, there were 209 approvals, with 70\% concentrated in 10 countries: Democratic Republic of Congo (DRC), Zambia, Nigeria, Algeria, South Africa, Sudan, Tanzania, Ethiopia, Ghana and Chad. More than half of the approvals were for mineral extraction and a third were for prospecting.
Approvals for mining investment in the 2 eco-regions accounted for $45 \%$ of all mining records for Africa. The DRC, Zambia and Tanzania accounted for $90 \%$ of mining sector approvals, the vast majority $(86 \%)$ of which were for mineral extraction and prospecting activities.

In the forestry sector, there were 34 investment approvals in 14 countries. The top intended investment destinations for Chinese forestry companies in Africa are Gabon, Zambia, Ghana, Nigeria and Republic of Congo. Overall, Gabon accounts for almost $23 \%$ of forestry sector approvals. Eighteen of the 34 approvals were in the 2 ecoregions, and over $40 \%$ of these were in Gabon. Timber extraction and sawnwood manufacturing together account for most (84\%) of the approval records.

For crop-based agriculture, there were 35 records. Zambia, Tanzania, Sudan, Ghana and Ethiopia accounted for almost $60 \%$ of approval records. Most (74\%) approvals were for crop production, with smaller numbers for wholesale and retail $(20 \%)$ and manufacturing (5.7\%) activities. Overall, 43\% of agricultural approvals were in the 2 eco-regions, almost half of which were for investment in Zambia.

Globally, mergers and acquisitions (M\&A) by Chinese companies have been increasing in recent years. Africa is the second most frequent destination for mining M\&A events, and research shows increased interest in M\&A activity in Africa. Most M\&A activity is in the oil and mining sectors.

Further research is required to produce a comprehensive database of actual Chinese investment activities in Africa. M\&A as a growing form of overseas investment by Chinese companies also merits investigation. 


\section{摘要}

中国对非洲投资和贸易的影响已成为国际上备 受瞩目的焦点。在此背景下, 国际林业研究中 心启动了 “中国在非洲的贸易和投资” 项目。 该项目以可能对森林有直接影响的矿业、林业 和农业3个部门为重点, 旨在通过在非洲两个生 态区, 即刚果盆地和非洲南部森林地区开展研 究以了解中国对与森林有关的全球贸易流和投 资模式的作用和影响。

由于相关数据的缺乏, 使得全面了解中国在非 洲的投资, 分析发展趋势和模式比较困难。因 此, 本文以中国商务部的企业海外投资审批记 录（1983年至2010年）为基础，建立了中国对 非洲投资数据库。该数据库记录了计划从事海 外投资活动的企业, 但并不意味着投资活动已 经实施。此外本文还使用了其他相关数据来源 对中国在非洲上述领域的兼并和收购趋势进行 了说明。

该数据库记录了1988年至2010年间所有被批准 在非洲进行投资的中国企业, 共计1346条，占 所有中国海外投资记录的 $8.47 \%$ 。在 2002 年之 前, 每年获得批准的企业不超过10个。而2002 年以后, 这一数字则以每年 $250 \%$ 的速度递 增。2010年，获得批准的投资企业达到了388 个。在所有记录中，284个涉及矿业、林业和农 业的投资，129个（约44\%) 位于本项目的研 究区域。

同时，矿业共涉及209个投资记录，其中 $70 \%$ 集中在刚果（金）, 赞比亚, 尼日利亚, 阿
尔及利亚, 南非, 苏丹, 坦桑尼亚, 埃塞俄比 亚, 加纳和乍得 10 个国家，45\%位于项目关 注的两个生态地区。在所有矿业投资中, 超过 $50 \%$ 的为矿业开发，另有超过 $30 \%$ 为矿业勘 探。在涉及 2 个生态区的矿业投资记录中, 刚果 （金），赞比亚和坦桑尼亚是主要的投资地, 占了 $90 \%$, 其中绝大多数 $(86 \%)$ 为矿产开采 和勘探。

林业部门共有 34 个投资记录, 涉及14个国家, 主要的投资目的地为加蓬, 赞比亚, 加纳, 尼 日利亚和刚果（布），其中加蓬占了近 $23 \%$ 。 两个生态地区涉及了 18 个投资记录，其中 $40 \%$ 位于加蓬, 而木材采伐和锯材制造业占大多数 (84\%)。

以作物种植为基础的农业共有35条审批记录。 赞比亚, 坦桑尼亚, 苏丹, 加纳和埃塞俄比亚 占了近 $60 \%$ 。其中大多数 $(74 \%)$ 为作物生 产，小部分为批发及零售业 $(20 \%)$ 和制造业 (5.7\%) 的活动。总体而言， $43 \%$ 的农业批准 记录位于 2 个生态区, 其中近一半是在赞比亚。 此外, 在全球范围内, 近年来由中国公司发起 的兼并和收购活动也在逐渐增加。而非洲则是 中国采掘业的第二大兼并和收购目的地。研究 表明, 中国在非洲进行并购活动的兴趣正在不 断增加, 并主要集中在石油和矿业部门。

今后的研究将集中在建立较为全面的中国对非 洲投资数据库。同时作为一种的投资新形式, 兼并和收购同样值得关注。 


\section{Résumé}

Les conséquences des investissements et des échanges de la Chine avec l'Afrique font l'objet de nombreuses conjectures. Le projet du CIFOR intitulé " Chinese trade and investment in Africa " (Le commerce et les investissements chinois en Afrique) cherche à comprendre quel est le rôle de la Chine dans le fait que les flux d'échange mondiaux et les politiques d'investissement se déplacent vers les forêts dans deux régions écologiques de l'Afrique, à savoir le bassin du Congo et les forêts d'Afrique australe, en mettant l'accent sur les secteurs ayant un potentiel impact direct sur les forêts : l'exploitation minière, la foresterie et l'agriculture.

Dans la mesure où il n'existe pas de base de données complète sur les investissements chinois réalisés en Afrique, il est difficile de brosser un tableau et d'analyser les tendances et les caractéristiques. Dans ce document de travail, l'analyse repose sur l'enregistrement, dans une base de données (19832010), des autorisations accordées par le Ministère du commerce de la République populaire de Chine (MOFCOM) aux sociétés chinoises pour qu'elles investissent à l'étranger. Cette base de données enregistre les intentions d'investir à l'étranger des sociétés, mais pas les investissements réellement réalisés. D'autres sources sont utilisées pour caractériser les tendances en matière de fusionsacquisitions chinoises dans les secteurs considérés en Afrique.

La base de données contient 1346 enregistrements d'autorisations à investir en Afrique délivrées aux sociétés chinoises entre 1988 et 2010 , ce qui représente $8,47 \%$ de l'ensemble des autorisations d'investissement à l'étranger accordées aux entreprises chinoises. Avant 2002, moins de 10 autorisations étaient délivrées chaque année. À partir de 2002, ce nombre a augmenté d'en moyenne $250 \%$ par an, pour atteindre 388 autorisations en 2010. Sur ce nombre, 278 ont concerné les secteurs minier, forestier et agricole, dont 128 (44\%) dans les deux régions d'intérêt écologique pour le projet du CIFOR.

Dans le secteur minier, 209 autorisations ont été accordées, 70 \% d'entre elles étant concentrées dans 10 pays : la République démocratique du Congo (RDC), la Zambie, le Nigeria, l'Algérie, l'Afrique du Sud, le Soudan, la Tanzanie, l'Éthiopie, le Ghana et le Tchad. Plus de la moitié des autorisations ont concerné l'extraction minière, un tiers la prospection. Les autorisations d'investissement minier dans les deux régions écologiques ont représenté $45 \%$ de tous les dossiers miniers pour l'Afrique. La RDC, la Zambie et la Tanzanie ont représenté $90 \%$ des autorisations dans le secteur minier, dont une grande majorité (86\%) pour des activités d'extraction et de prospection.

Dans le secteur forestier, 34 autorisations d'investissement ont été accordées dans 14 pays. Les premières destinations d'investissement visées par les sociétés forestières chinoises en Afrique sont le Gabon, la Zambie, le Ghana, le Nigeria et la République du Congo. Dans l'ensemble, le Gabon représente presque $23 \%$ des autorisations dans le secteur forestier.

Dix-huit des 34 autorisations ont concerné les deux régions écologiques et plus de $40 \%$ de celles-ci ont été attribuées au Gabon. L'extraction de bois et la fabrication de bois scié représentent à elles deux la majorité des autorisations enregistrées (84\%).

Dans le secteur de l'agriculture basée sur les cultures, on dénombre 35 enregistrements. La Zambie, la Tanzanie, le Soudan, le Ghana et l'Éthiopie ont représenté presque $60 \%$ des autorisations enregistrées. La plupart d'entre elles (74\%) ont concerné la production de cultures, beaucoup moins les activités de gros et de détail $(20 \%)$ et les activités manufacturières $(5,7 \%)$. Au total, $43 \%$ des autorisations agricoles ont été accordées dans les deux régions écologiques, dont presque la moitié pour des investissements en Zambie.

À l'échelle mondiale, le nombre de fusions-acquisitions (M\&A) réalisées par des sociétés chinoises augmente ces dernières années. L'Afrique est la deuxième destination la plus fréquente en matière de fusionsacquisitions minières, et des études font état d'un intérêt accru dans l'activité de M\&A en Afrique. La plus grande partie de celle-ci se produit dans les secteurs pétrolier et minier.

D’autres études sont nécessaires pour établir une base de données complète sur les investissements chinois réellement réalisés en Afrique. Les fusions-acquisitions, en tant que moyen de plus en plus utilisé par les sociétés chinoises pour investir à l'étranger, méritent également d'être étudiées. 


\section{Introduction}

The 'Chinese trade and investment in Africa: Assessing and governing trade-offs to national economies, local livelihoods and forest ecosystems' project, launched in March 2010, aims to advance understanding of the social, economic and environmental impacts of Chinese investment in commodities or sectors affecting forests and livelihoods in Africa (e.g. timber, mining, agriculture), and to strengthen the capacity of decision-makers in government, civil society and the private sector to enact reforms to maximise social and economic benefits while minimising adverse effects.

This project seeks to understand China's role in shifting global trade flows and investment patterns; to understand what is unique about Africa's trade with China (relative to other development partners) in the forestry sector; and to identify how trends in forest-related trade and investment are playing out in the Congo Basin and the southern African woodlands. These regions were selected because of the importance of their forests. The countries of concern in these eco-regions are Republic of Congo, Cameroon, Democratic Republic of Congo (DRC), Equatorial Guinea, Gabon, Mozambique, Tanzania, Zambia and Zimbabwe. Together these countries have a total area of 6.3 million $\mathrm{km}^{2}$, spanning more than a fifth of the total African land mass. The project is identifying the economic, social and environmental trade-offs (positive and negative impacts) for a selection of Chinese investments that have an impact on forests on the continent (e.g. timber, agricultural cash crops, biofuels, mining).

In recent years, in line with China's 'Going Out' strategy announced in 2000 (MOFCOM 2001), many Chinese companies have begun exploring and making investments in Africa. The impacts of this trend - both positive and negative - have generated a great deal of speculation worldwide. A growing number of reports from academics and civil society organisations document some of these activities and, in some cases, the specific impacts on the local ecology, livelihoods and economy. However, nowhere have specific investment events been systematically collated, making it difficult to build a picture and analyse trends and patterns from the available scattered documentation. One part of this project is to develop systematic documentation of investment events in the Congo Basin and southern African woodlands.

In the absence of a complete database, the analysis in this working paper draws on a database of applications by Chinese companies for permission to invest overseas. The database is the China Companies Overseas Investment Database of the Ministry of Commerce of the People's Republic of China (MOFCOM). The MOFCOM database contains a list of Chinese companies that received approval to make overseas green land investments during the period 1983-2010. The database was built to comply with Chinese government regulations, first issued in 1983 and subsequently updated several times, that require Chinese companies intending to make non-trade investments overseas to apply to MOFCOM for approval to invest (State Council 1983, MOFTEC 1984, 1985, 1992, 1999, NPC 1991, MOFCOM, 2003, 2007, 2009). Listing in the database can only be taken as an indication of a company's intent to invest overseas. Listing does not imply that all these companies eventually made the actual investments either in Africa or in the sectors under which they applied. There are 2 other caveats to note. First, the database does not include merger and acquisition (M\&A) or other minority equity investments. Since the database does not include companies solely involved in M\&A investment, this working paper describes some trends in Chinese M\&A (see Section 5). Second, the database does not record the value of intended investments. The relevant Chinese government agencies record outward foreign direct investment (OFDI) value data separately and report them using other systems.

Drawing primarily on the MOFCOM database, this working paper examines trends in intended investment and the major intended investment destinations of Chinese companies in 3 important land use sectors that may have direct environmental and social impacts: forestry, mining and agriculture. The analysis focuses on data for companies intending to invest in these sectors in countries of the Congo Basin and southern African woodlands (Congo, Cameroon, DRC, Equatorial Guinea, Gabon, Mozambique, Tanzania, Zambia and Zimbabwe). Section 5 analyses available data on M\&A investments in these sectors drawing on other data sources. The final section elaborates on some questions for further research raised by the analysis. 


\section{Approvals for investment by Chinese companies in Africa}

\subsection{Trends in investment approvals}

Examination of the MOFCOM database identified 1346 records of Chinese companies declaring their intention to invest in Africa, covering the period from 1988 to 2010 . This accounts for $8.47 \%$ of the total number (15 895) of records in the MOFCOM database. Although the first record in the database dates back to 1983, the first investment record in Africa is in 1988, when Jiangxi International Economy and Technology Cooperation Corporation, a state-owned company, applied to set up a representative office in Zambia.

To help understand trends in investment approvals, the period 1988-2010 can be divided into 2 phases. The first phase is from 1988 to 2001, during which time fewer than 10 companies obtained approval from MOFCOM each year. The second phase is from 2002 to 2010, during which time the record of investment applications grew dramatically, with an average annual growth rate of $250 \%$. In 2010 , there were 388 records of approvals, which is nearly 40 times as many as in 2002.

\subsection{Investment destinations of approvals for Africa}

The 1346 investment records found referred to 45 African countries, or around $85 \%$ of the continent. The top 10 intended investment destinations for Chinese companies are Nigeria, South Africa, Zambia, Egypt, Ethiopia, Angola, Tanzania, DRC, Algeria and Ghana. Records

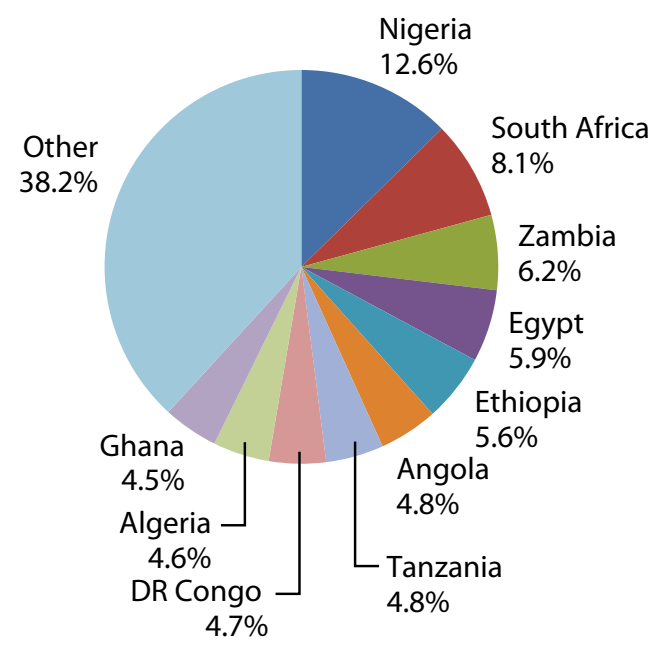

Figure 2. Top 10 Chinese intended investment destinations in Africa

Source: MOFCOM China Overseas Investment Database, compiled by the authors

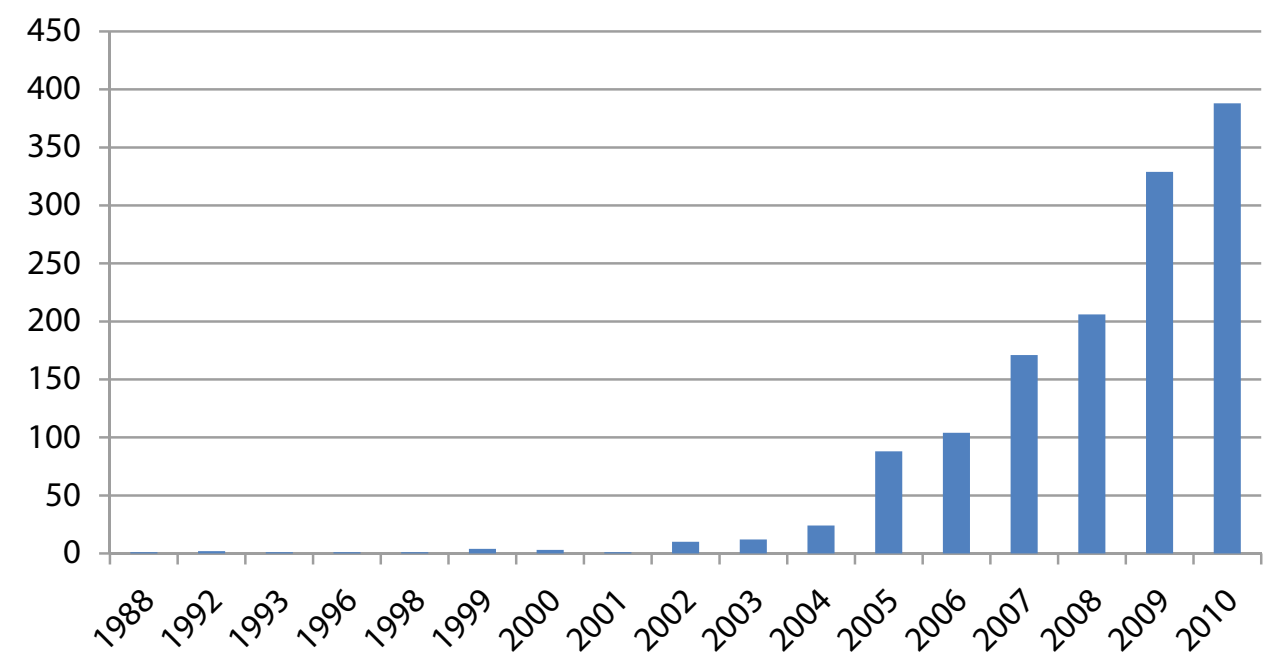

Figure 1. Number of companies receiving approval to invest in Africa (1988-2010)

Source: MOFCOM China Overseas Investment Database. Compiled by the authors 
referring to these 10 countries account for $61.8 \%$ of the total number of companies approved to invest in Africa.

\subsection{Intended investments by type and sector}

To analyse the intended investments by sector, we adopted the classification in the Chinese National Economy Industry Classification and Code (GB/T 4754-2002), a national standard applied in China. Application of this classification method reveals that Chinese companies mainly intend to invest in 8 economic sectors: manufacturing; leasing and business services; wholesale and retail; construction; mining; research, technical services and geological prospecting; farming, forestry, animal husbandry and fisheries; and real estate ${ }^{1}$ (Figure 3).

Amongst these sectors, manufacturing is the most frequent investment target, accounting for around $27.6 \%$ of all approvals. This industry category covers manufacturing across all industries, including textiles, chemicals, mining, wood processing and food processing. The leasing and business services sector is the second largest intended investment sector for Chinese companies, accounting for more than 21\% of the total number of records. This sector includes a large number of representative offices intending to make investments or to expand marketing of their products, many of which have the purpose of searching for potential business opportunities and clients in Africa. Companies engaging in international trade are categorised as being in the wholesale and retail industry, which accounts for almost $14 \%$ of all investment records. The construction industry, which includes construction activities such as housing, roads, railways and bridges, accounts for just over $12 \%$ of records. The mining sector is also an important investment field for Chinese companies, accounting for over $9 \%$ of records. It should be noted, however, that in this method of classification, mining only includes mineral extraction activities, such as extraction of oil, natural gas, metal and non-metal ores. Other miningrelated activities are classified into other sectors, such as research, technical services and geological

1 The China National Economy Industry Classification and Code (GB/T 4754-2002) is a 3-tier hierarchical list, with more detailed items under each main level.

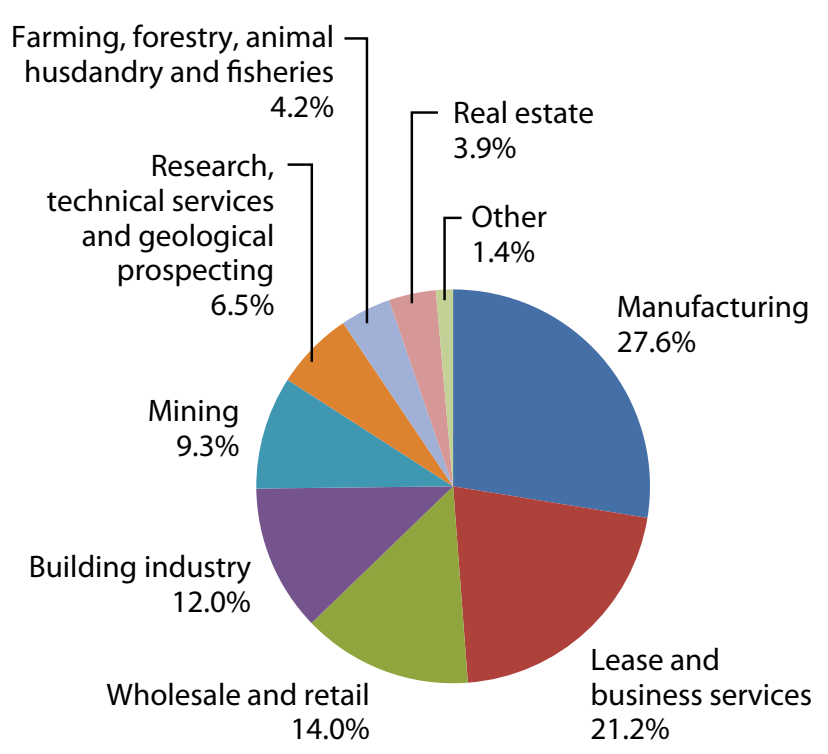

Figure 3. Composition of investment approvals in Africa by economic sector (1988-2010)

Note: To better understand the composition of investments from China in Africa, the analysis in this figure draws on the first level of 'Classification and Code'.

Source: MOFCOM China Overseas Investment Database, compiled by the authors

prospecting. The classification that includes agriculture, animal husbandry, fisheries and forestry in one category can be considered 'agriculture' in its broadest sense. This sector accounts for just over $4 \%$ of the total number of records.

\section{Approvals for Chinese companies investing in Africa's mining, forestry and agriculture sectors}

\subsection{Overview}

As mentioned above, many mining, forestry and agriculture companies' approvals to invest in Africa are classified under other economic sectors, such as manufacturing, wholesale and retail, and geological prospecting. In this section, we separate mining, forestry and agriculture out of the general 'agriculture' category, and include records relating to these 3 sectors that are allocated to other sectors using the standard classification presented above. In the mining sector, records referring to metal and non-metal ores (e.g. quarries) are sometimes difficult to distinguish, and some non-metal mining 


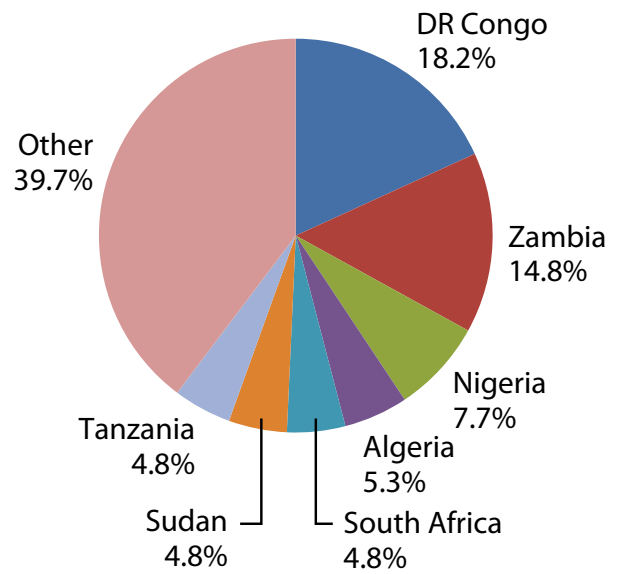

Figure 4. Major Chinese mining investment approval destinations in Africa

Source: MOFCOM China Overseas Investment Database, compiled by the authors

investment approvals may be included in the mining sector.

This re-categorisation results in 278 records relating to the mining, forestry and agriculture sectors, accounting for more than one-fifth of the total investment application records. There are 209, 34 and 35 records in the mining, forestry and agriculture sectors, respectively, or around 15\%, 2.6\% and 2.6\% of all investment application records.

\subsection{Mining investment approvals in Africa}

\section{Country distribution}

The re-categorised database shows a total of 209 records in the mining sector, distributed across 33 African countries. The top 10 intended investment destinations of these companies are DR Congo, Zambia, Nigeria, Algeria, South Africa, Sudan, Tanzania, Ethiopia, Ghana and Chad. Records referring to these 10 countries account for just under $70 \%$ of all mining sector records.

\section{Sector distribution}

Mining-related records are mainly distributed across five sectors of the standard classification: mineral extraction, geological prospecting, manufacturing, leasing and business services and wholesale and retail. Mineral extraction is the most common of these, accounting for $55 \%$ of all mining-related records.
Geological prospecting is also an important intended activity, accounting for around $31 \%$ of records.

Some of these records refer to companies that provide mineral prospecting services to other enterprises, while others are for companies intending ultimately to extract the ores discovered through prospecting. Manufacturing and leasing and business services each account for around $6 \%$ of total mining records, and the wholesale and retail industry accounts for just under $2 \%$ of records (Figure 5 ).

The mining industry also includes 14 oil companies, of which 12 obtained approvals to engage in oil extraction and 2 in manufacturing (Table 1).

\subsection{Forestry investment approvals in Africa}

Thirty-four forestry investment records distributed across 14 African countries cover forest management, logging, wood processing, paper and furniture and wooden floor materials manufacturing.

\section{Country distribution}

The top investment destinations for Chinese forestry companies in Africa are Gabon, Zambia, Ghana, Nigeria and Republic of Congo, among which Gabon is the most important, accounting for almost $40 \%$ of the total records. Gabon is an important African timber provider to China; it's rich forest resources and a comparatively stable political environment, have attracted Chinese

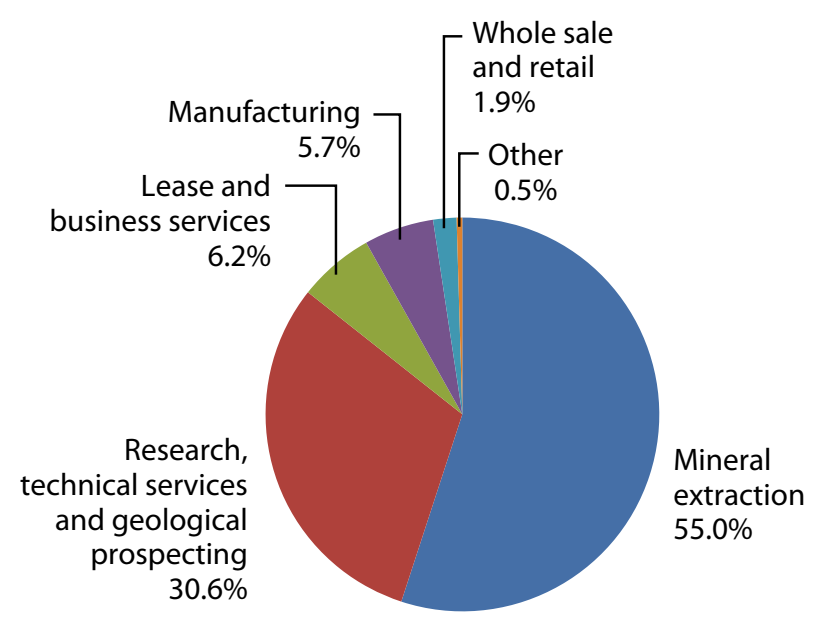

Figure 5. Sectoral distribution of Chinese mining investment approvals

Source: MOFCOM China Overseas Investment Database compiled by the authors 
Table 1. Sectoral distribution of Chinese mining investment approvals

\begin{tabular}{lcc}
\hline Sector & $\begin{array}{c}\text { Investment } \\
\text { records }\end{array}$ & $\begin{array}{c}\text { No. of which are oil } \\
\text { investment records }\end{array}$ \\
\hline Mineral extraction & 115 & 12 \\
Research, technical services and geological & 64 & 0 \\
prospecting & 13 & 0 \\
Leasing and business services & 12 & 2 \\
Manufacturing & 4 & 0 \\
Wholesale and retail & 1 & 0 \\
Other & $\mathbf{2 0 9}$ & $\mathbf{1 4}$ \\
Total & & 0 \\
\hline
\end{tabular}

Source: MOFCOM China Overseas Investment Database, compiled by the authors

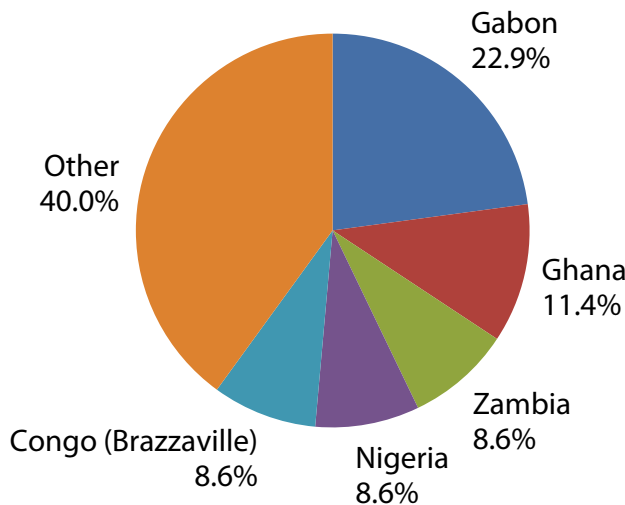

Figure 6. Top five destinations in Africa for intended forestry investments by Chinese companies

Source: MOFCOM China Overseas Investment Database, compiled by the authors

forestry companies (Forest Trends 2007). Exports of roundwood from Gabon to China have accounted for around $40 \%$ of African roundwood exports to China in recent years.

\section{Sectoral distribution}

Within the forestry sector, about $45.7 \%$ of investment approvals were for forest resources extraction (forest management and logging). Other activities included processing of wood products (wood-based panelling, etc.), paper and paper products and furniture manufacturing, which account for around $22.9 \%, 20.0 \%$ and $11.4 \%$, respectively (Figure 7).

When logging and sawnwood processing are categorised as 'primary processing' and other

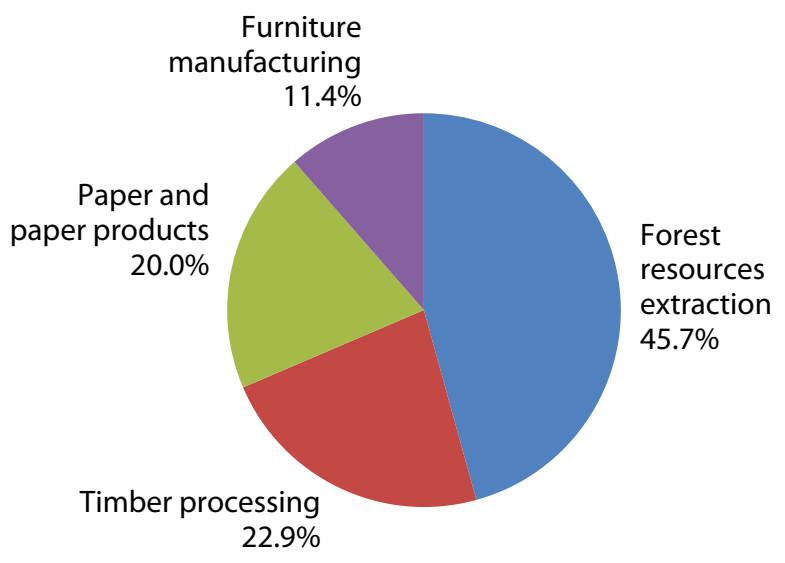

Figure 7. Sectoral distribution of Chinese forestry investment approvals

Source: MOFCOM China Overseas Investment Database, compiled by the authors

activities as 'secondary processing', 18 records $(52.9 \%)$ fall into the primary processing sector and $16(47.1 \%)$ into the secondary processing sector.

\subsection{Agricultural investment approvals in Africa}

In this section, we consider agriculture only narrowly defined as cropping, i.e. excluding forestry, animal husbandry and fisheries. Applying this narrow definition, 35 records are found in this sector.

\section{Country distribution}

The 35 investment records are distributed across 17 African countries. Zambia, Sudan, Tanzania, Ethiopia and Ghana are the major investment destinations, accounting for almost $60 \%$ of the total 
investment approval records. Amongst these five countries, Zambia is the most frequently represented, accounting for almost $20 \%$ of the total number of records.

\section{Sectoral distribution}

Most approvals in the agriculture sector are in crop production. The other sectors recorded are wholesale and retail and manufacturing, accounting for $20.0 \%$ and $5.7 \%$, respectively (Figure 9).

\section{Chinese mining, forestry and agriculture investment approvals in the eco-regions}

\subsection{Overview}

This research project focuses on the Congo Basin and southern African woodlands because of the importance of their remaining forests. The countries of concern in these two eco-regions are Cameroon, DR Congo, Equatorial Guinea, Gabon, Mozambique, Republic of Congo, Tanzania, Zambia and Zimbabwe. Together, these countries cover 6.3 million $\mathrm{km}^{2}$, more than one-fifth of the total African land area.

The MOFCOM database includes 293 investment records in these countries, which, at less than $22 \%$, is not a very large share of the total records for Africa. However, of these, $44 \%$ (128 records) relate to mining, forestry and agriculture. This indicates that these sectors in these investment destinations are relatively significant for Chinese companies.

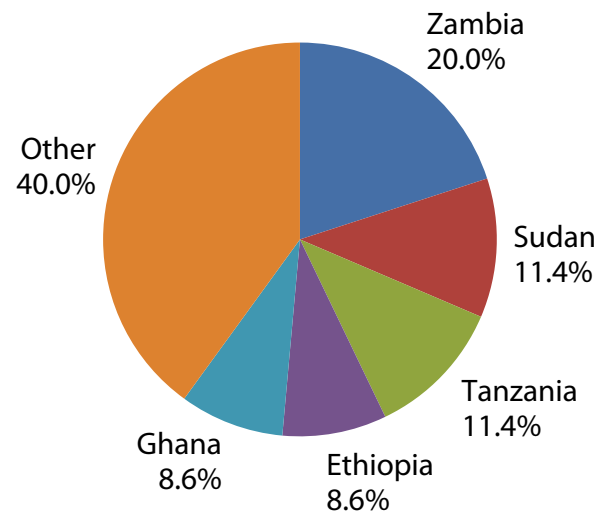

Figure 8. Major Chinese agriculture investment approval destinations in Africa

Source: MOFCOM China Overseas Investment Database, compiled by the authors

\subsection{Mining investment approvals in the eco-regions}

\section{Country distribution}

A total of 95 records for the mining sector in these countries account for over $45 \%$ of the total mining records for the African continent. The major destinations for mining investment are DR Congo, Zambia and Tanzania. These three countries combined account for over $90 \%$ of mining investment records in the eco-regions (Figure 10).

\section{Sectoral distribution}

When records are analysed by economic sector, mineral extraction is seen to account for a large share (64\%). Extraction and geological prospecting together account for $86 \%$ of the total mining sector investment records. No oil-related records were found in the target eco-regions.

\subsection{Forestry investment approvals in the eco-regions}

\section{Country distribution}

There are a total of 18 investment approval records for the forestry sector in the Congo Basin and southern woodlands eco-regions, accounting for almost $53 \%$ of the total forestry records in Africa. Gabon is the most frequent intended investment destination, accounting for more than $40 \%$ of the total investment records in the eco-regions.

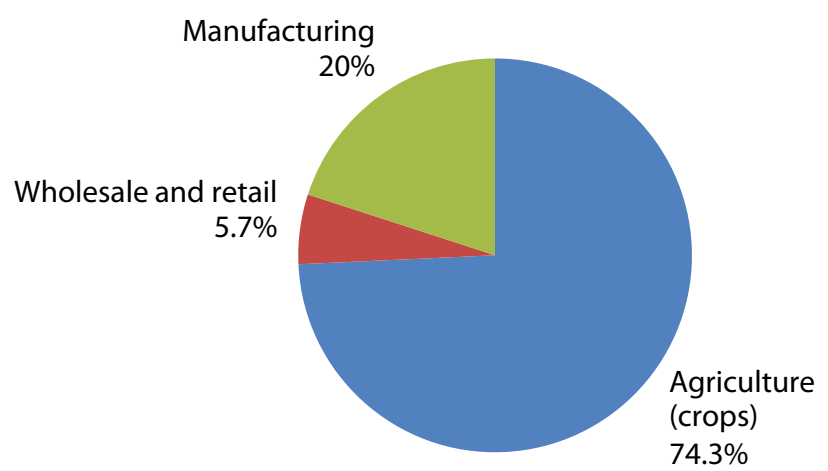

Figure 9. Sectoral distribution of Chinese agriculture investment approvals

Source: MOFCOM China Overseas Investment Database, compiled by the authors 


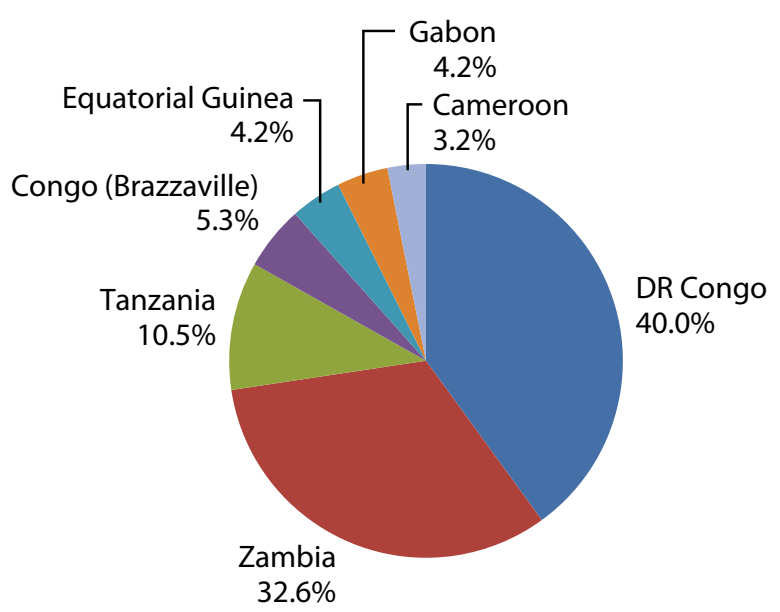

Figure 10. Major Chinese mining investment destinations in the eco-regions

Source: MOFCOM China Overseas Investment Database, compiled by the authors

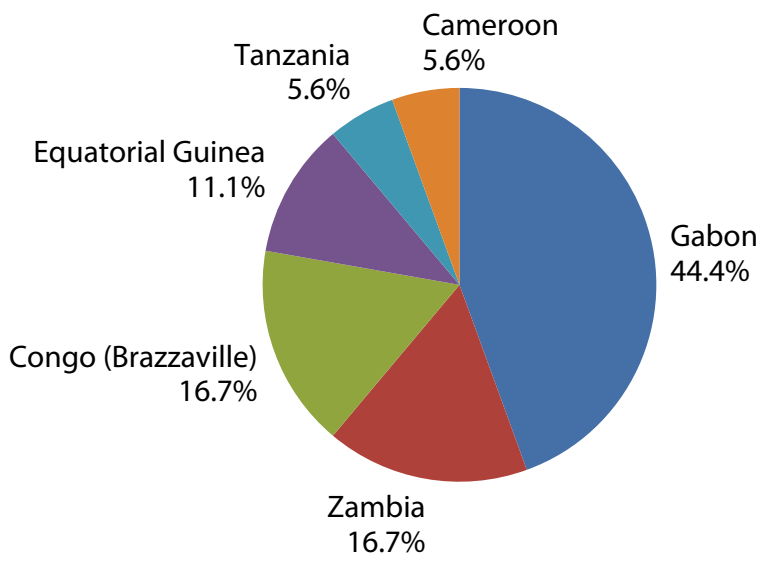

Figure 12. Major Chinese forestry investment destinations in the eco-regions

Source: MOFCOM China Overseas Investment Database, compiled by the authors

\section{Sectoral distribution}

When we look at the sectoral distribution of Chinese forestry investment in the study countries, we find that primary processing (i.e. timber extraction and sawnwood manufacturing) accounts for most (84\%) of the records (Figure 13).

\subsection{Agricultural investment approvals in the eco-regions}

For agriculture, the MOFCOM database includes 15 records in the eco-regions, accounting for over

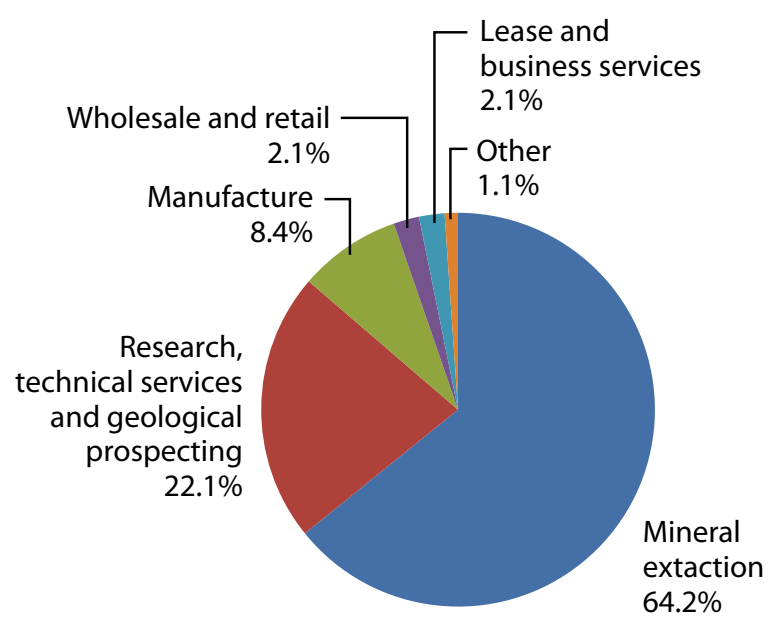

Figure 11. Sectoral distribution of Chinese mining investment approvals in the eco-region

Source: MOFCOM China Overseas Investment Database, compiled by the authors

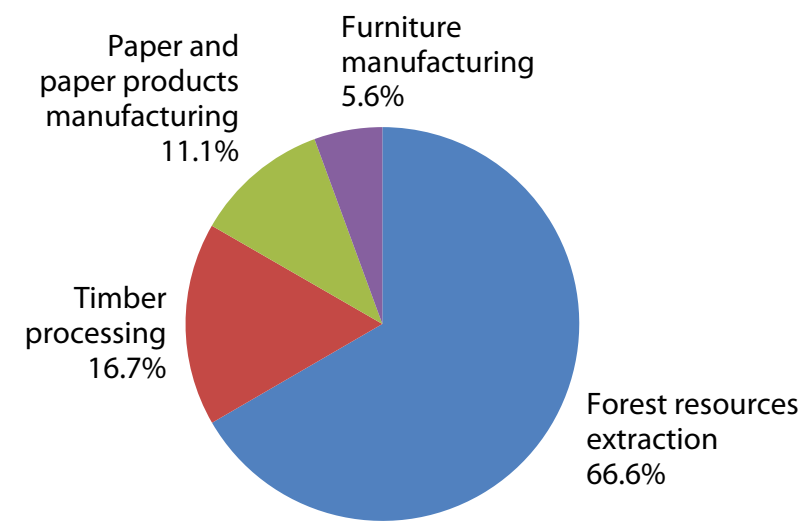

Figure 13. Sectoral distribution of Chinese forestry investment in the eco-regions

Source: MOFCOM China Overseas Investment Database, compiled by the authors

$42 \%$ of the total agricultural records for Africa. This indicates that these regions are important Chinese agricultural investment destinations.

Amongst the countries in the two eco-regions, Zambia is the most frequent intended investment destination, accounting for nearly half of all records. The potential for investment in Zambia makes southern Africa an important agricultural investment destination; together with Tanzania this sub-region accounted for over $73 \%$ of all investments in the two eco-regions. 
Of these, 13 records (87\%) are for intended investment in crop production, and two records are for manufacturing.

\section{Chinese companies' merger and acquisition activities in Africa}

In addition to the green land investments recorded in the MOFCOM database, Chinese companies have been engaged in a large number of overseas M\&A activities in recent years, many of which are in Africa. M\&A approvals are not included in the MOFCOM database. For insights into trends in this area, we rely on two reports compiled by Deloitte (2010a, 2010b). Deloitte's reports include only completed M\&A activity, and do not account for the likely large number of M\&A initiatives that are not followed through to completion.

From 2003 to mid-2010, Chinese overseas M\&A activity increased greatly in terms of both value and number (Figure 15).

Amongst these mergers and acquisitions, a large number (in terms of both quantity and value) were in the oil and mining sectors. These M\&A activities account for $39 \%$ of the total records Deloitte collated.
Amongst Chinese mining companies' M\&A target markets, Australasia is the most important destination, accounting for a quarter of total M\&A events. Africa is the second most important continent, accounting for $15 \%$ of the total records. It should be noted that some Australasian and other companies may have been taken over or purchased by Chinese companies that are also operating in Africa.

Deloitte (2010b) presents an analysis of possible future trends in Chinese outward M\&A activity in the mining sector. Using data from interviews with 26 Chinese mining companies with prior involvement in outward M\&A, Deloitte identified

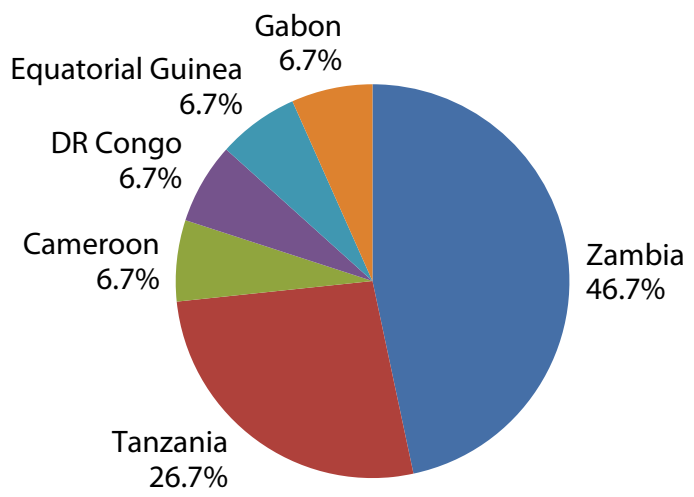

Figure 14. Major Chinese agricultural investment destinations in the eco-regions

Source: MOFCOM China Overseas Investment Database, compiled by the authors

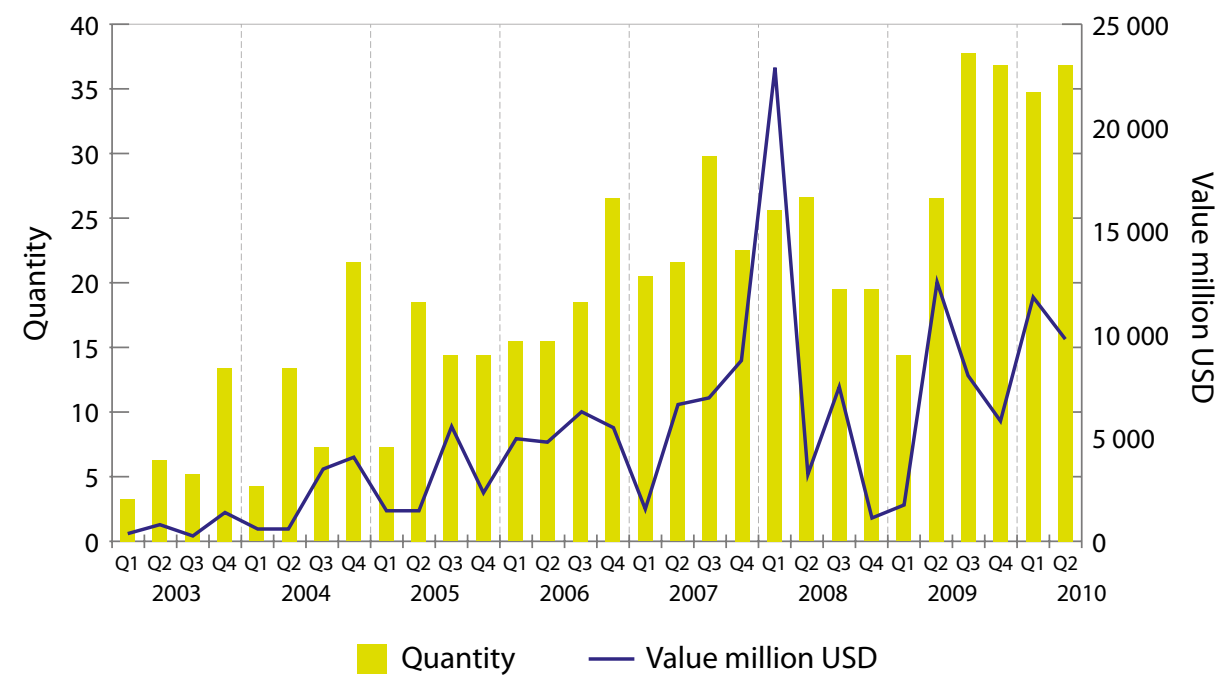

Figure 15. Chinese overseas merger and acquisition events (2003 to mid-2010) Source: Deloitte (2010a) 
33 Chinese outward M\&A events in the mining sector in 2009, representing US\$9.2 billion of investment. Most of the M\&A events involved the purchase of majority or minority stakes in the overseas company. Most interviewed respondents revealed that they expected Chinese outward M\&A activity to increase in 2010-2011. The most commonly cited driver of this anticipated trend was the goal of securing resources supply. Increasing market share, achieving economies of scale and price bargaining power were also frequently mentioned drivers. Environmental protection concerns were the third most commonly mentioned obstacle to M\&A deals, after currency regulations and financial market instability. Africa was by far the most frequently cited potential future destination for outward M\&A. Reasons given for this include the complementarity between Africa's abundant resources and Chinese companies' ability to invest, low labour costs and the then (pre-July 2010) threatened imposition of a super-profits tax in Australia that made acquisitions in other countries relatively more attractive. Drivers explaining Chinese companies' need to secure raw materials supply in the mining sector are reviewed in Zhang (2011).

\section{Discussion}

The analysis of records of Chinese government approvals for participation in overseas investment by Chinese companies shows 1346 investment records of intent to invest in Africa. This is equivalent to less than $8.5 \%$ of the total number of approvals for Chinese companies to invest overseas. Amongst the specific sectors of concern to this research project, mining investment in Africa is an important field for Chinese companies investing in Africa, accounting for $15 \%$ of the total number of investment records. DR Congo, Zambia, Nigeria, Algeria and South Africa are important mining investment destinations, accounting for nearly half of all investment approval records. The shares of forestry and agriculture are much smaller (about $2.6 \%$ each). The central and southern African eco-region countries are important mining, forestry and agriculture investment destinations for Chinese companies - a large part of all investment records for these three sectors across the African continent are concentrated in countries in these two eco-regions. Africa also accounts for

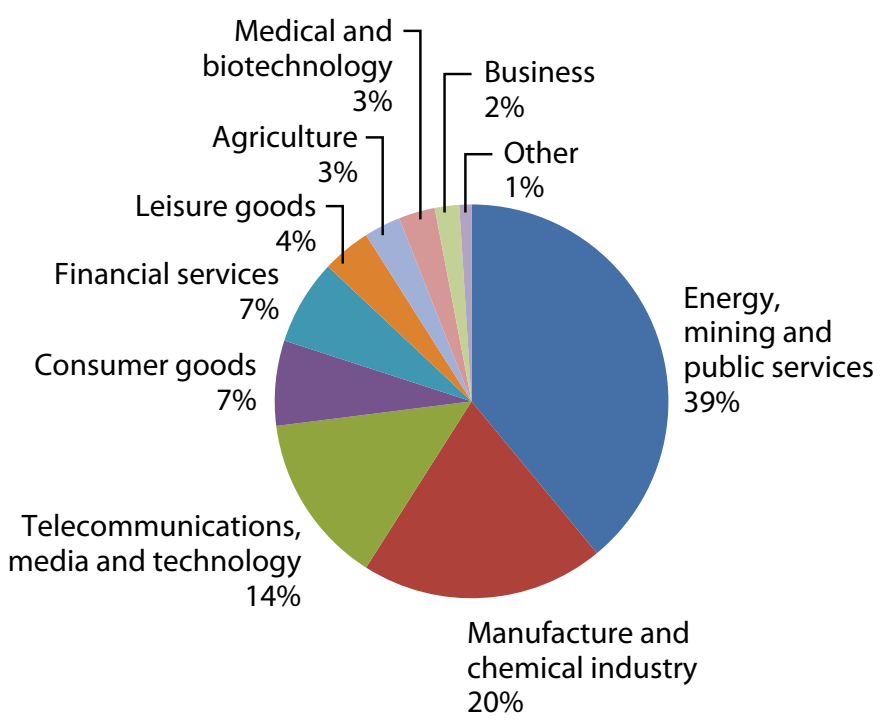

Figure 16. Sectoral composition of Chinese overseas merger and acquisitions by number of M\&A events (2003 to mid-2010)

Source: Deloitte (2010a)

a reasonable share of overseas M\&A activities by Chinese companies, being the second most frequent investment destination. By sector, energy, oil and mining are important target industries for Chinese companies' M\&A activities.

The analysis in this working paper draws mostly on a database recording approvals by MOFCOM for Chinese companies to invest overseas. The database does not record which of these companies subsequently went on to make the actual investments. Furthermore, since the database records only companies' intentions to invest overseas, it is possible that some companies with approval to invest overseas subsequently changed the country or sector of investment based on their original scoping and planning activities. The database cannot therefore be taken to indicate actual investments by Chinese companies. This can be illustrated with reference to the forestry sector. The MOFCOM database records 18 companies intending to invest in the forestry sector in the central and southern African eco-regions. Using the list of companies obtained from the MOFCOM database and cross-referencing against the list of companies recorded by China Customs as importing roundwood from Africa to China in 2008 and 2009 to search for online and media reports of investment events, 10 companies 
reported or claimed in their own media products to have made investments in forest management, and four companies reported that they made investments in wood product processing in Africa (Huang et al. 2011). However, in-country investigations (e.g. Putzel and Kabuyaya 2011) sometimes find that some claimed investments are in fact not operational, as occurs when concessions are subsequently withdrawn or when other factors impede investment activities. Further research would be required to identify which companies have gone on to undertake actual investments. Investigation of the reasons for success or failure in following through with investment intentions would increase understanding of the factors affecting investment decisions by Chinese firms.

Industry actors forecast that Chinese M\&A activities in Africa will increase in the short term. Another issue arising from the increased M\&A activity is whether international but Chinese-owned or partly owned companies are also active in the target sectors in Africa.

\section{References}

Deloitte 2010a Rising sun: a new chapter in China’s overseas merger and acquisitions. Deloitte, Beijing, China (in Chinese).

Deloitte 2010b Mining for growth: a review of outbound mining M\&A activity from China. Deloitte, Beijing, China.

Forest Trends 2007 Forest products trade between China and Africa: an analysis of import and export statistics. Forest Trends, Washington, DC.

Huang, W.B., Canby, K. and Sun, X.F. 2011 China forest products trade and investment. Unpublished report submitted by World Agroforestry Centre China \& East Asia Node to CIFOR, Bogor, Indonesia.

Ministry of Commerce of the PR China (MOFCOM) 2001 China commerce yearbook 2001. MOFCOM, Beijing, China.
Ministry of Foreign Trade and Economic Cooperation of PR China (MOFTEC) 1992. Approval and temporary management regulation for setting up non-trade overseas companies.

Ministry of Commerce of the PR China (MOFCOM) 2003 Circular about implementing well the approval reform pilots for overseas investments [Shanghezi (2003) No. 16].

Ministry of Commerce of the PR China (MOFCOM) 2007 Circular on adjusting the authorization of overseas investments [Shanghezi (2007) No. 112].

Ministry of Commerce of the PR China (MOFCOM) 2009 Management method for overseas investments [Shangwubuling (2009) No. 5].

Ministry of Foreign Trade and Economic Cooperation (MOFTEC) 1984 Circular about the approving authority and procedure of establishing the nontrade joint venture overseas.

Ministry of Foreign Trade and Economic Cooperation (MOFTEC) 1985. Approval procedure and administrative method for setting up non-trade management joint ventures overseas (temporary) [Waijingmaohefa (1985) No. 19].

National Planning Commission (NPC) 1991 Regulation on developing and approving project proposals and feasibility reports for overseas investments. [Jiwaizi (1991) No. 1271].

Putzel, L. and Kabuyaya, N. 2011 Forest-related impacts of Chinese aid, trade and investment in the Democratic Republic of Congo: preliminary observations. Unpublished report, CIFOR, Bogor, Indonesia.

State Council 1983 Circular on assignment of responsibility in foreign economy and trade. [Guofa (1982) No. 13].

Zhang, H. 2011. Trends in Chinese trade and investment in Africa's mining sector. Unpublished report submitted by World Agroforestry Centre China \& East Asia Node to CIFOR, Bogor, Indonesia. 


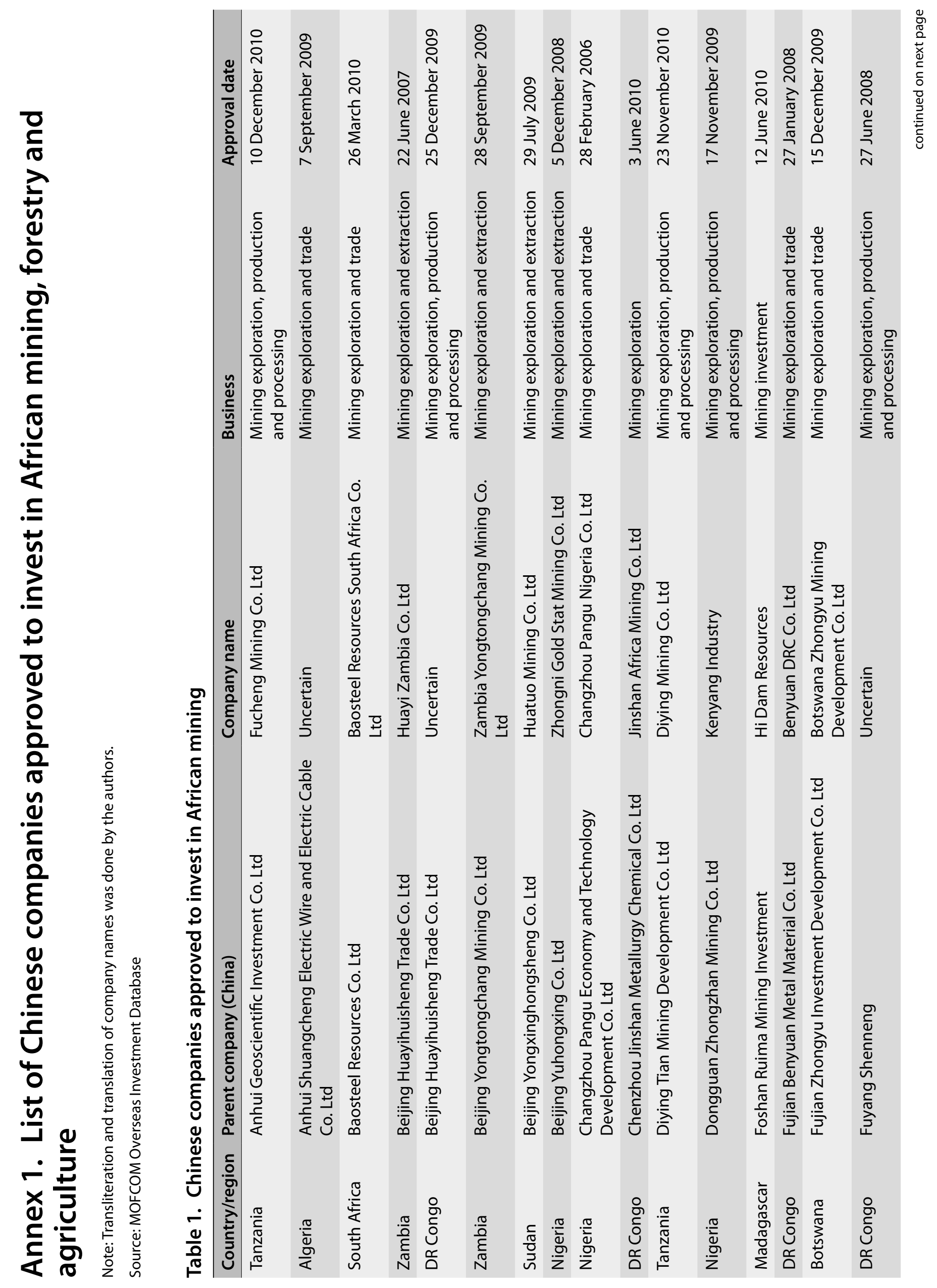




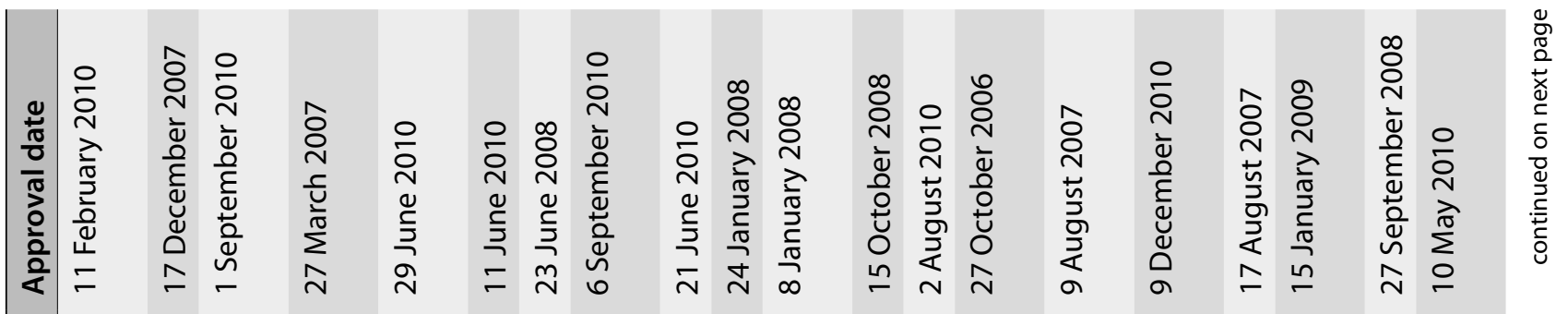

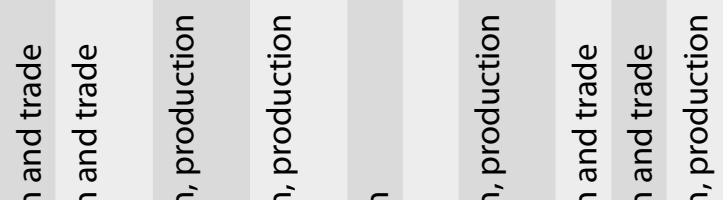

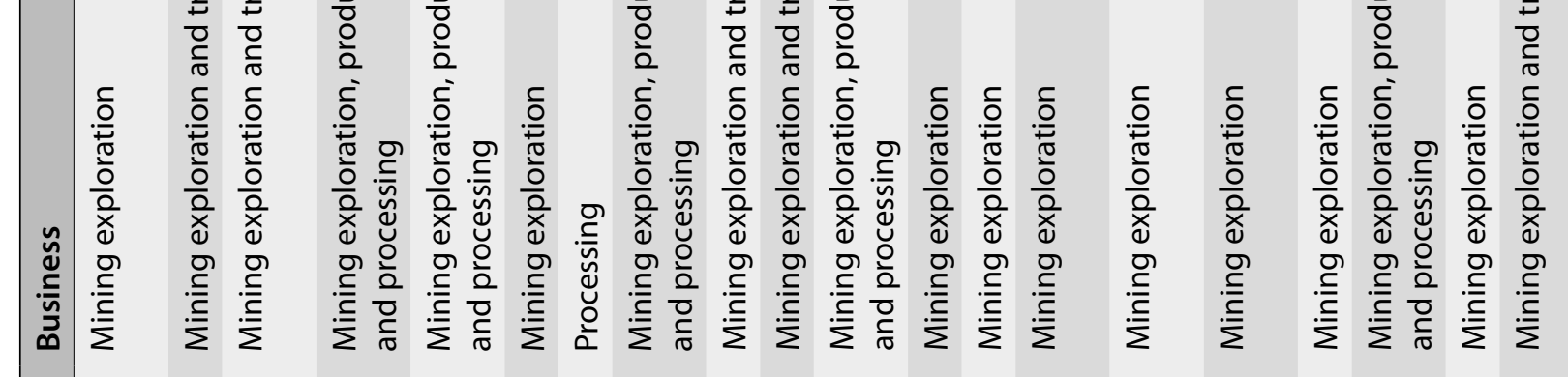

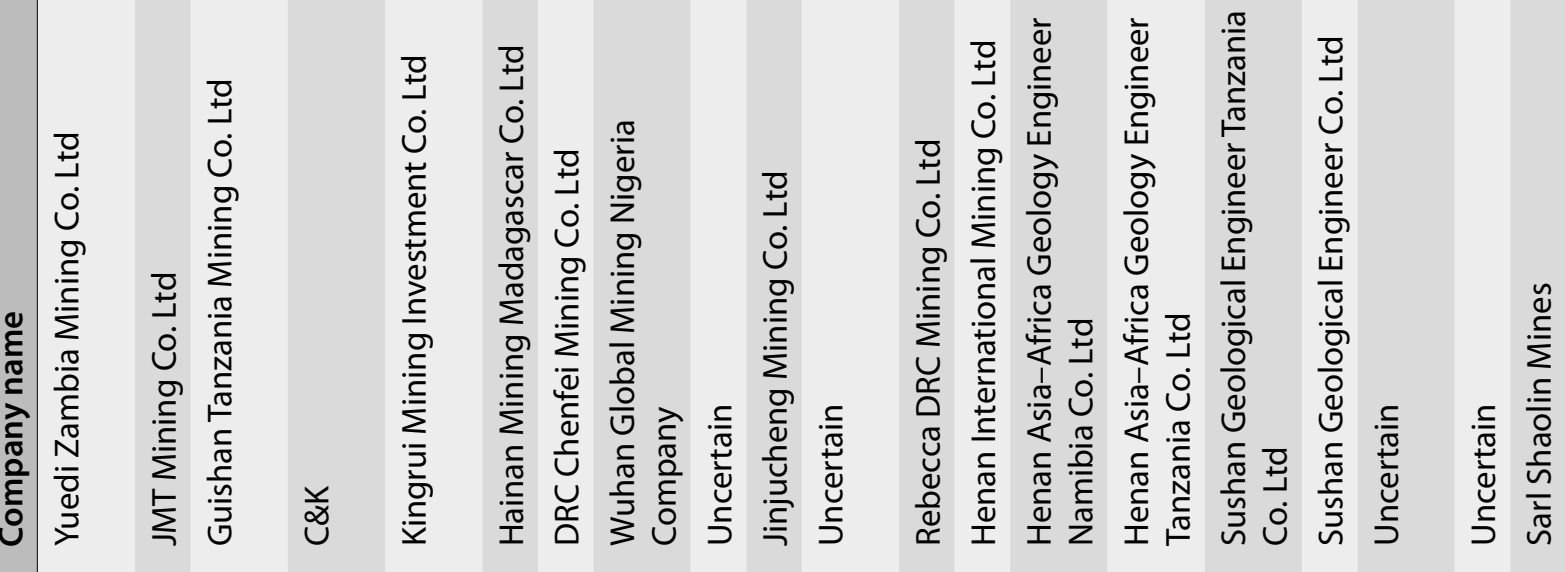

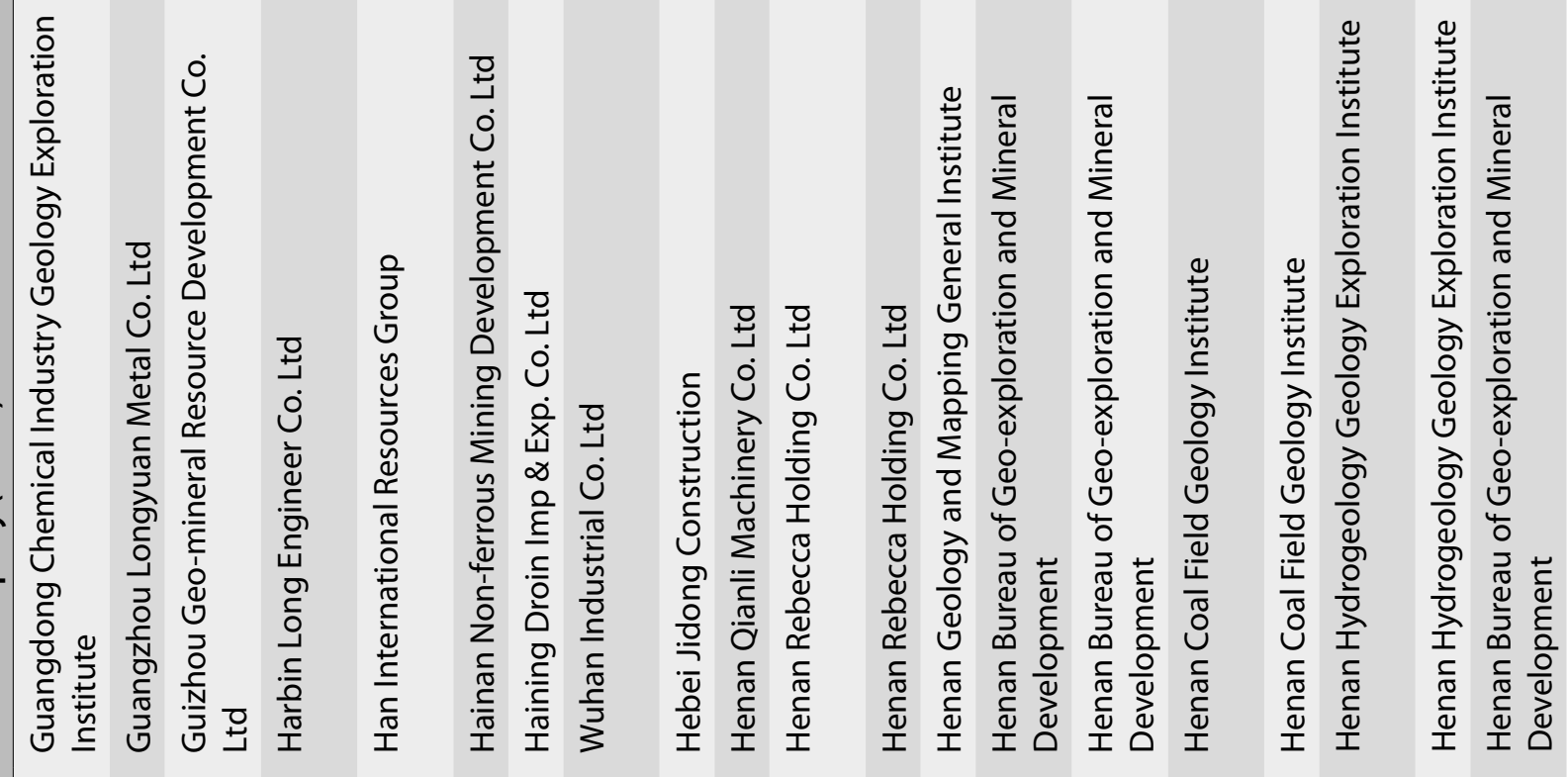




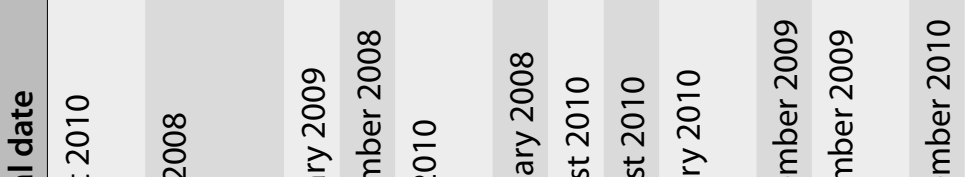

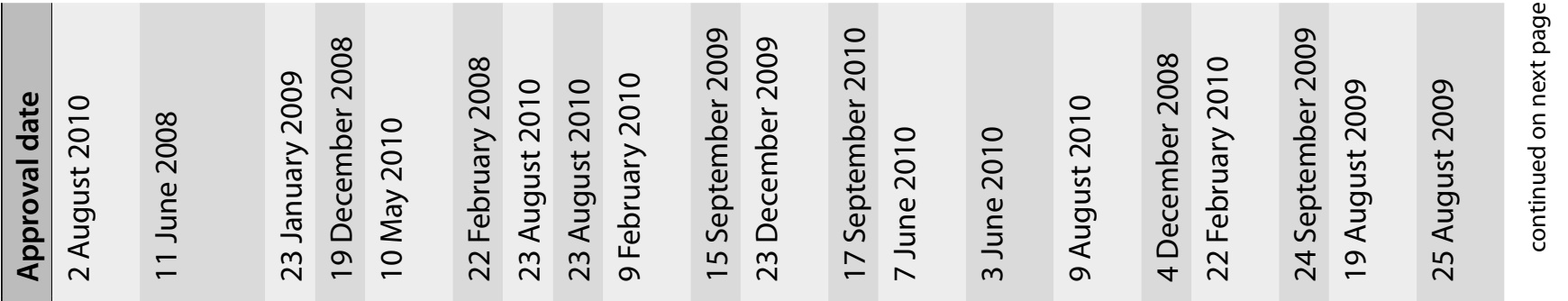

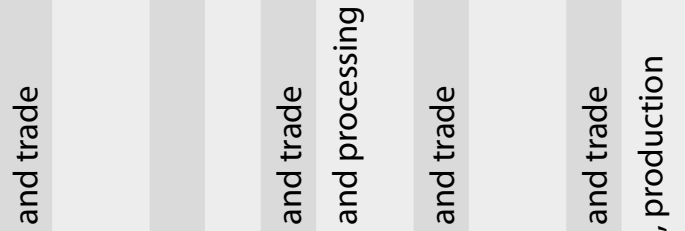

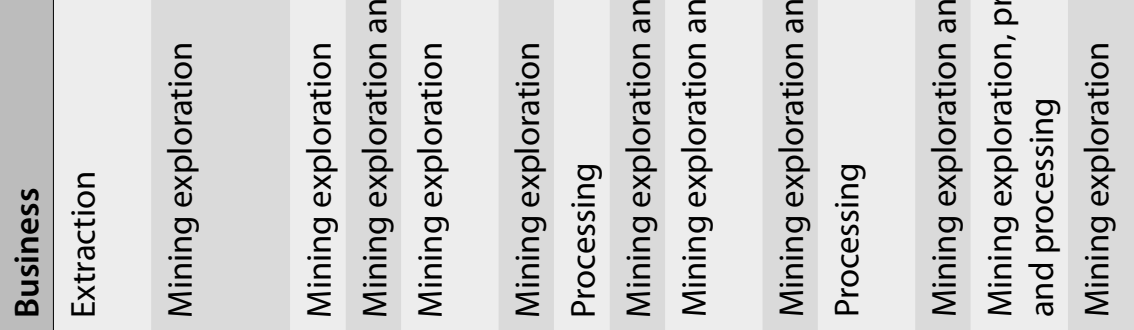

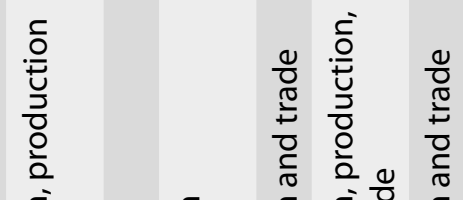

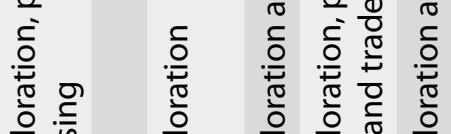

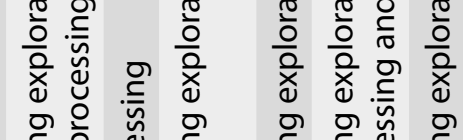

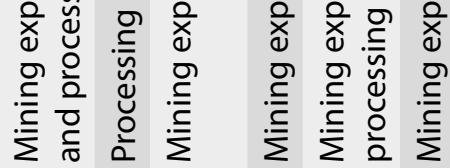

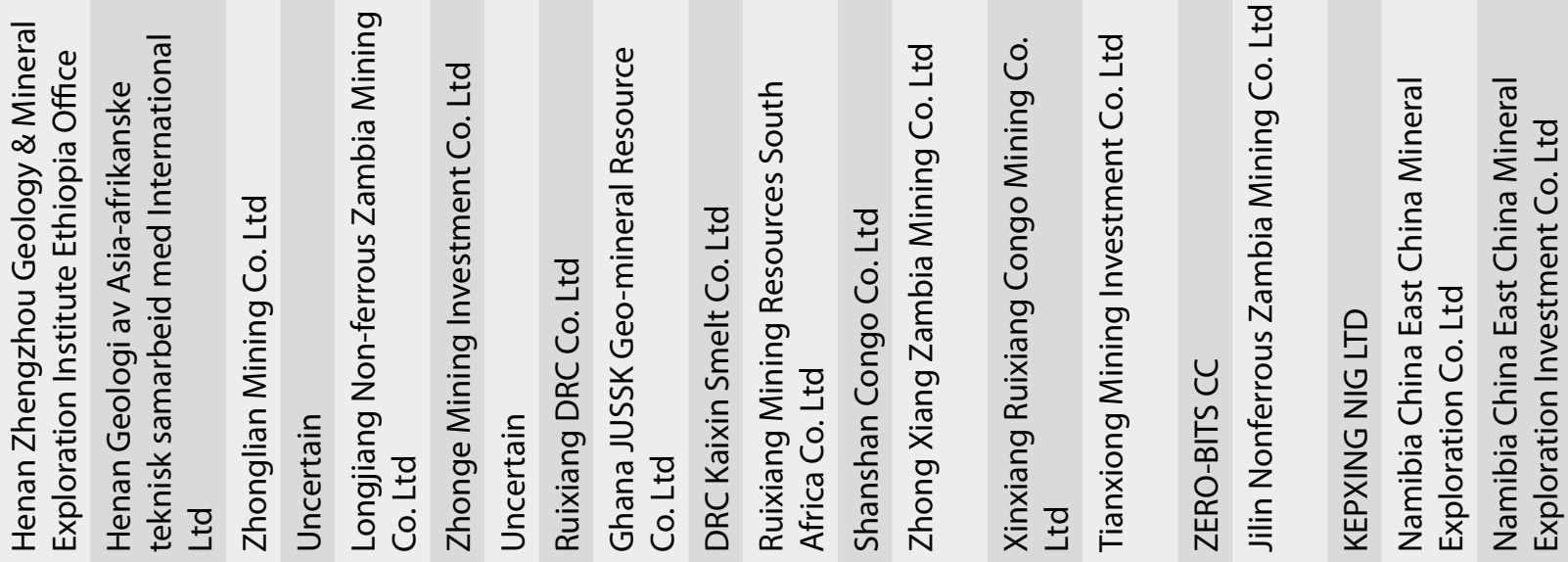

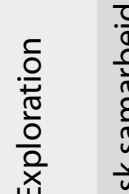

然

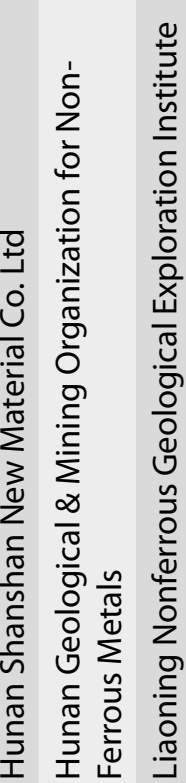

무 후 후

ن 0

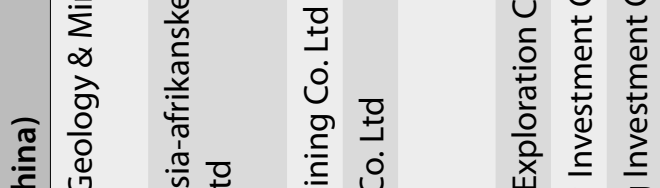

บ

离

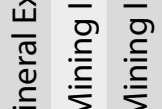

ह

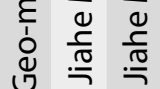

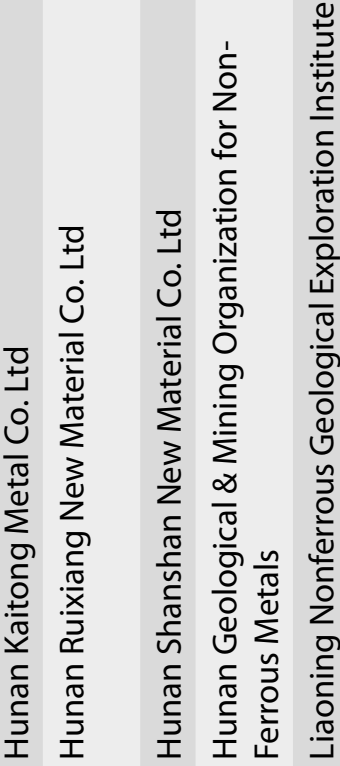


商

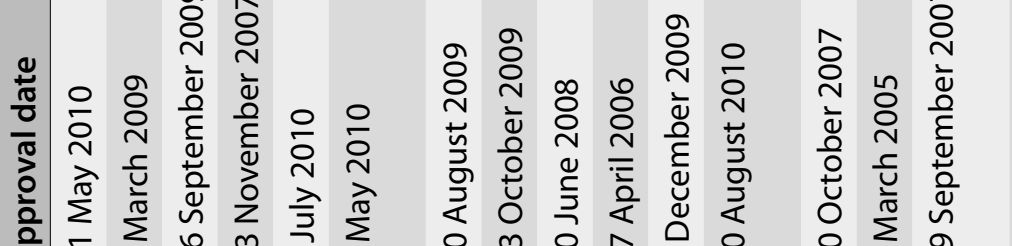

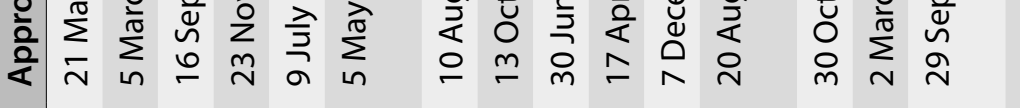

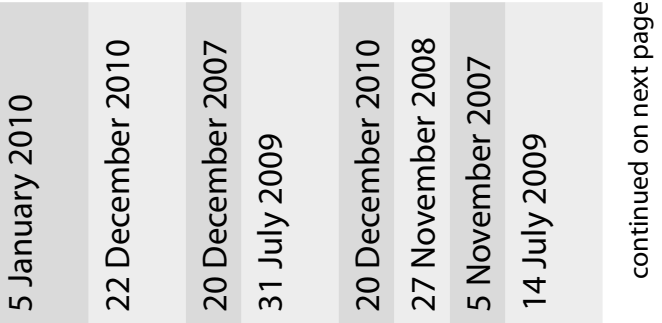

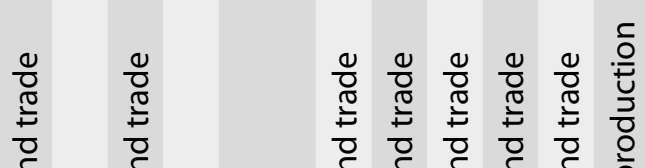

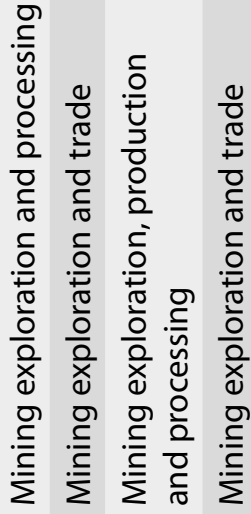

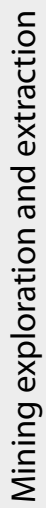

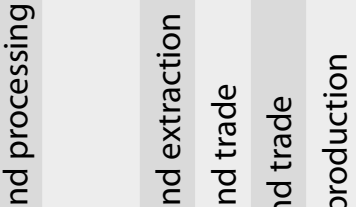

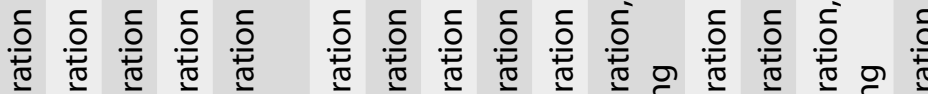

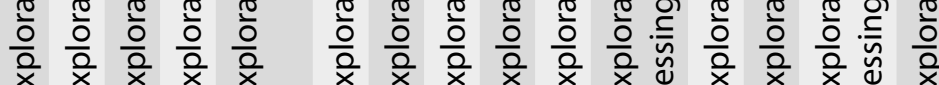

(⿱一兀)

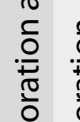

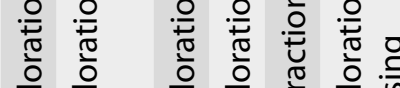

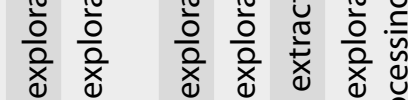

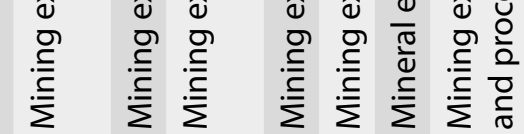

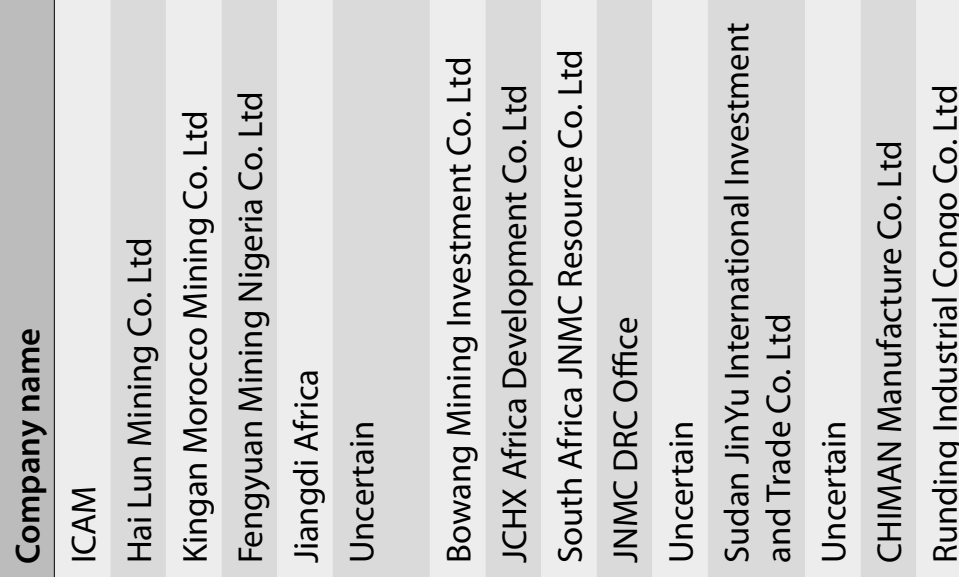

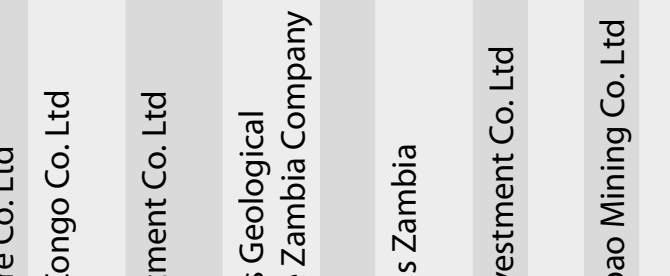

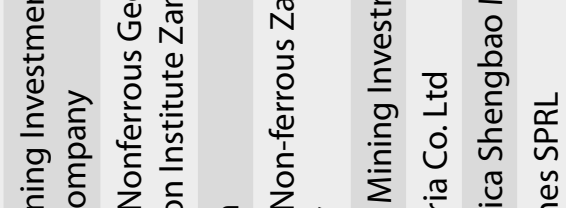

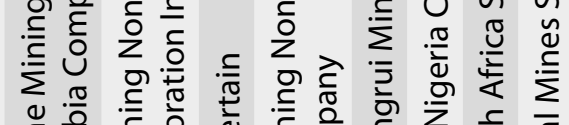

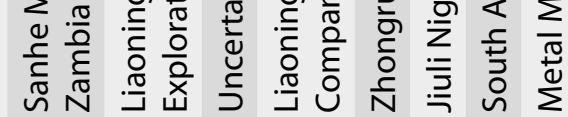

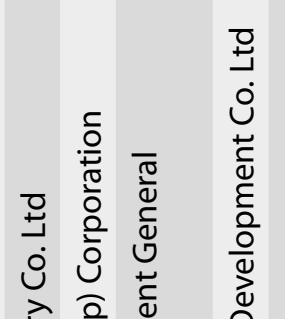

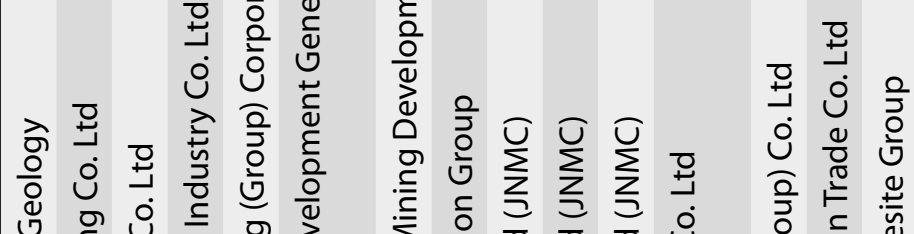

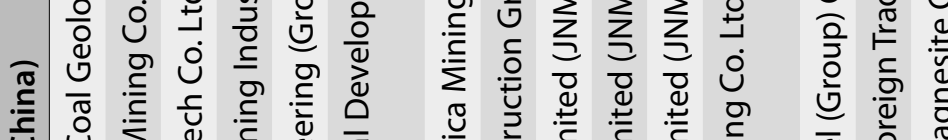

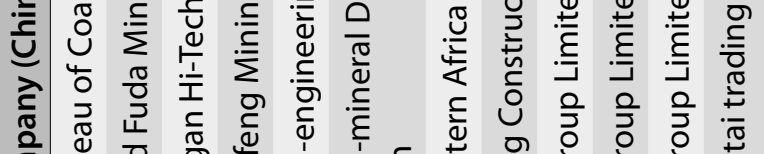

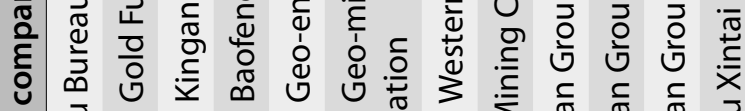

垔

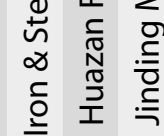

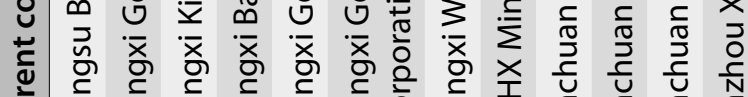

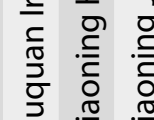

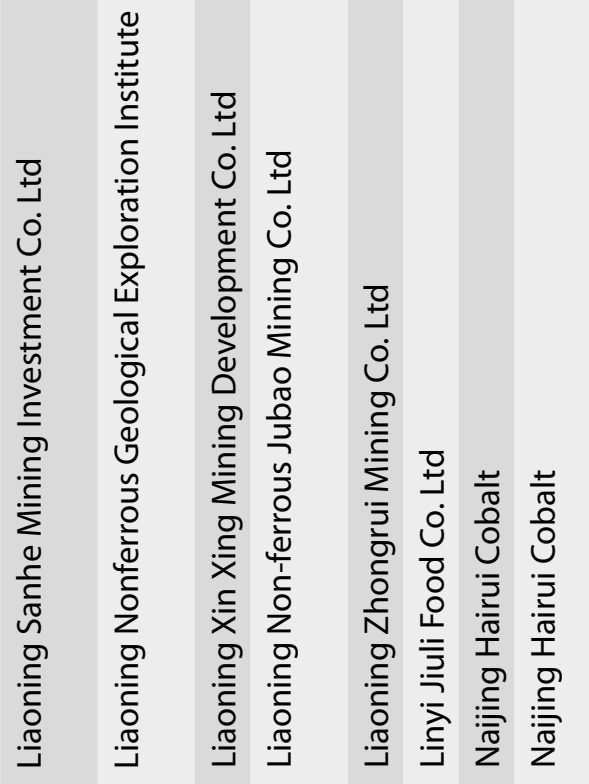

穵

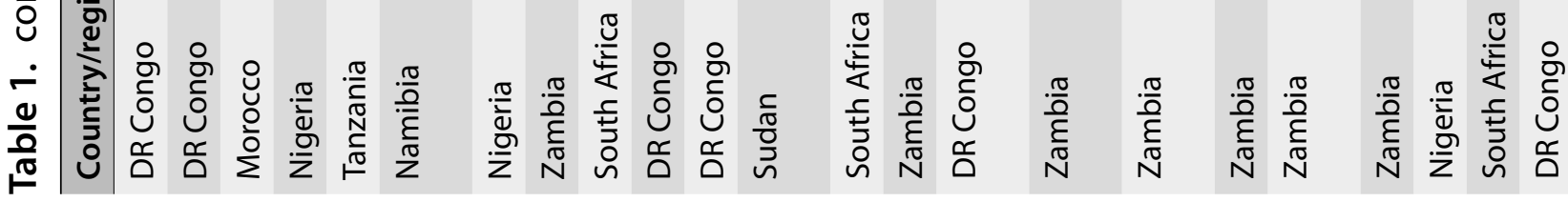




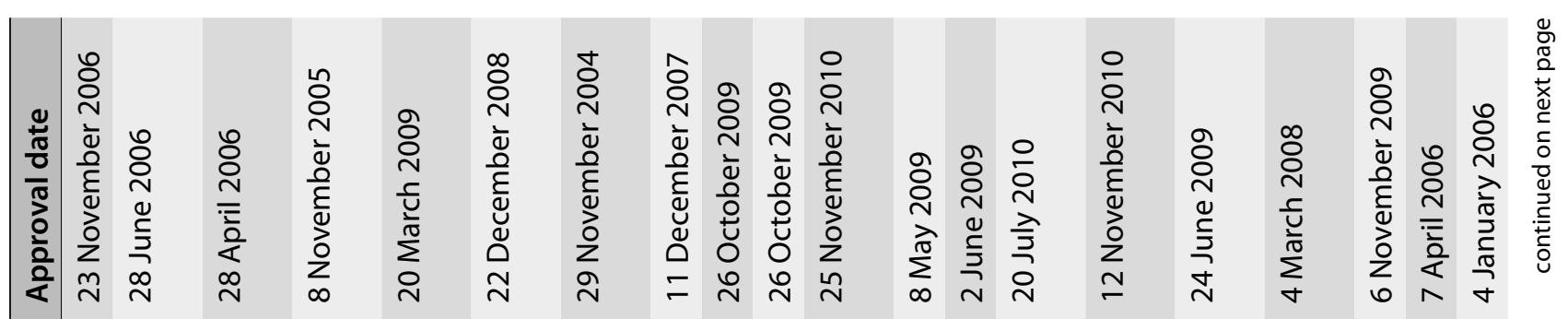

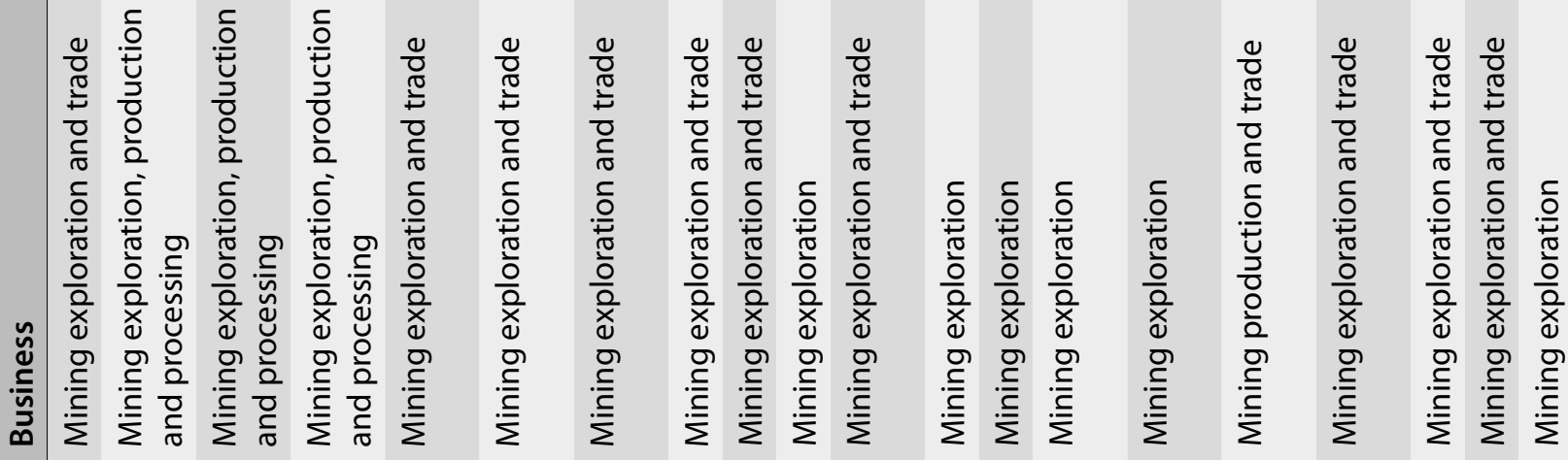

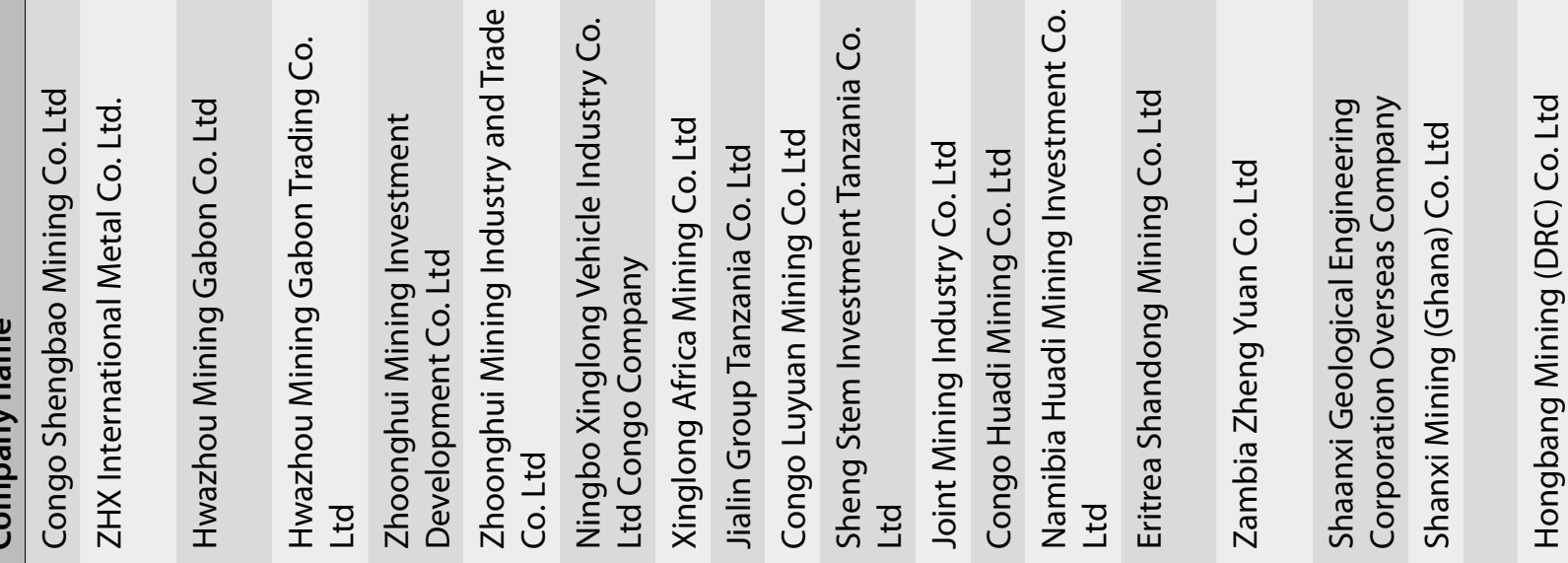

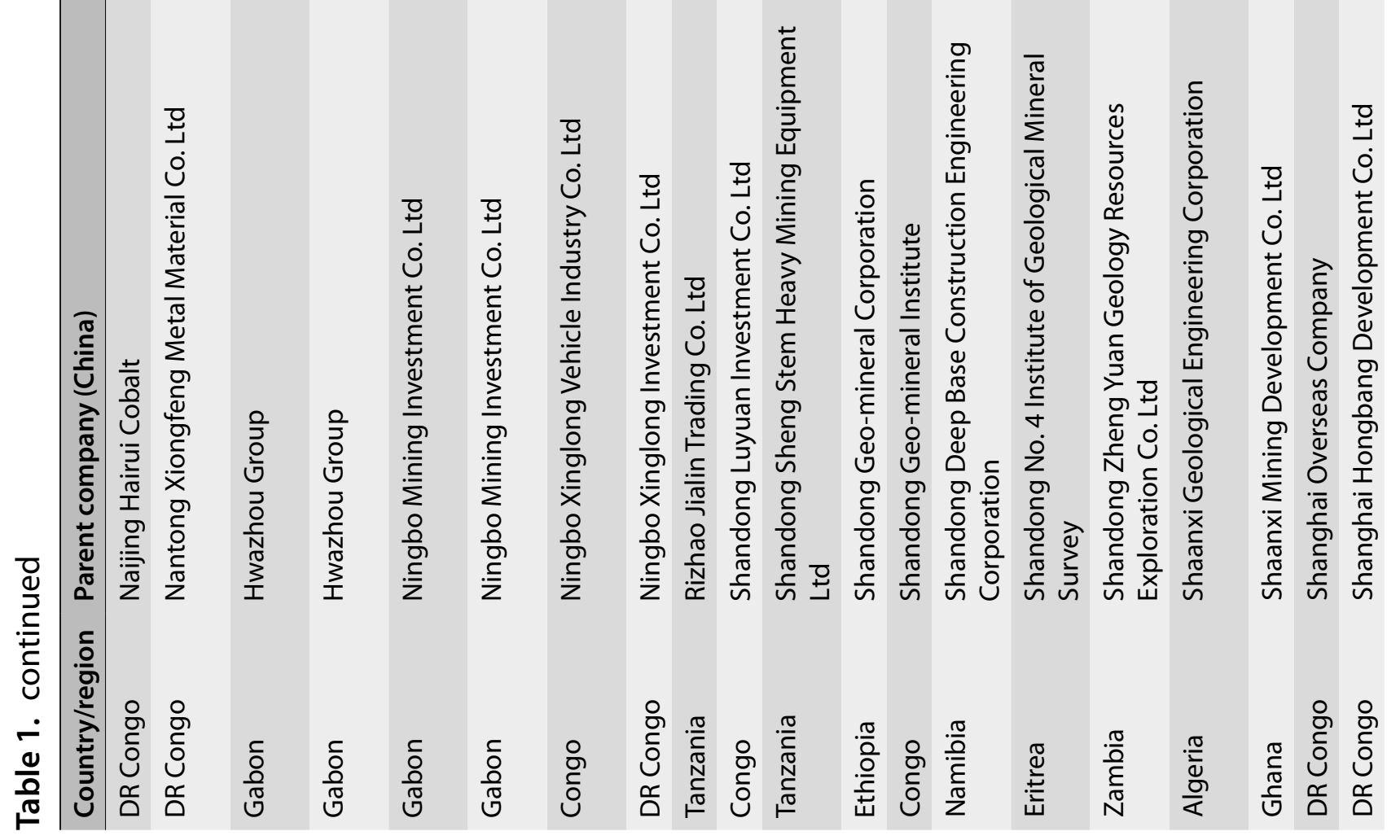




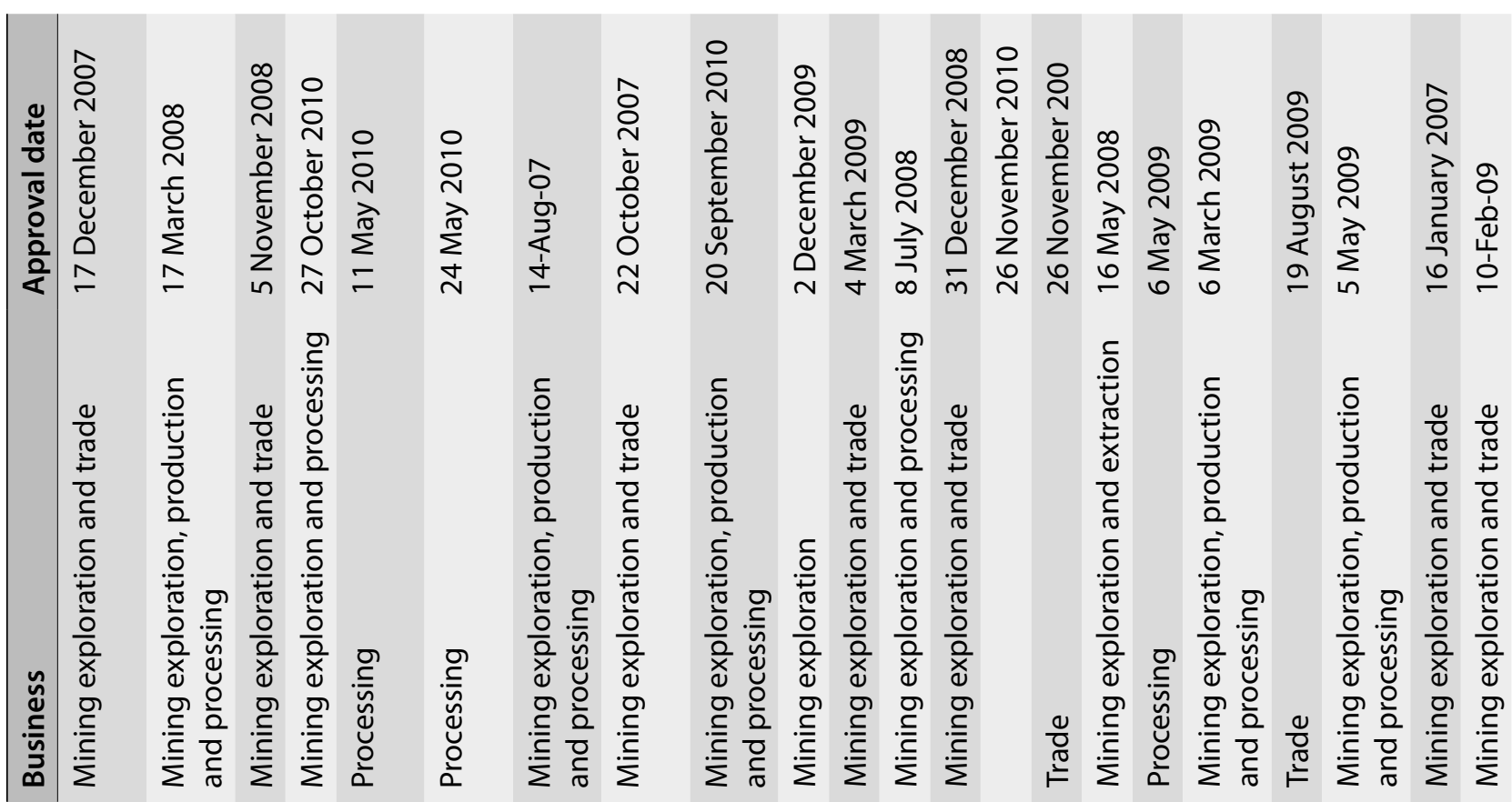

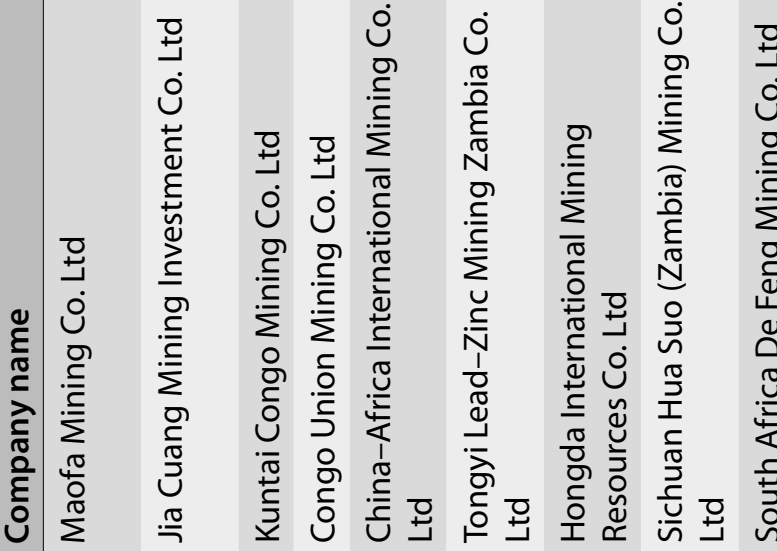

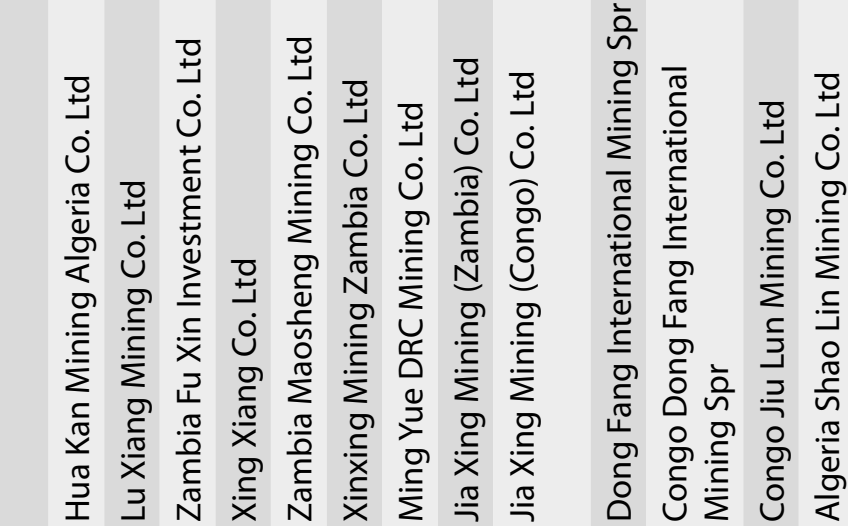

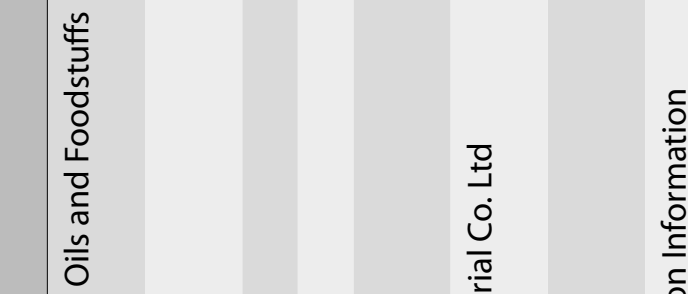
듬
꼼

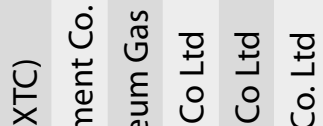
$\stackrel{\oplus}{\dot{\Xi}}$

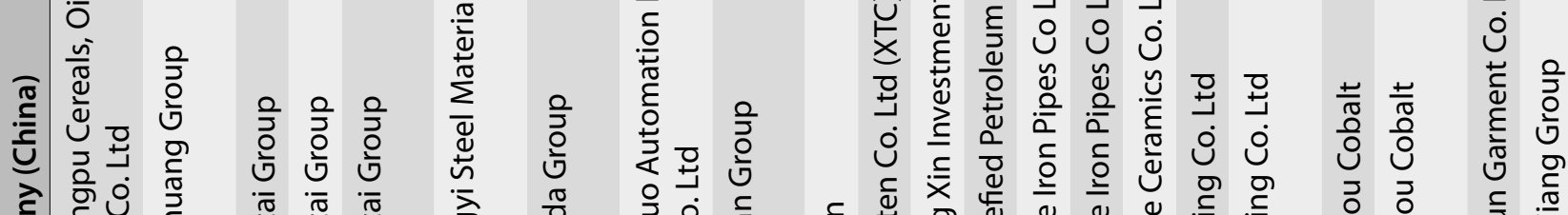

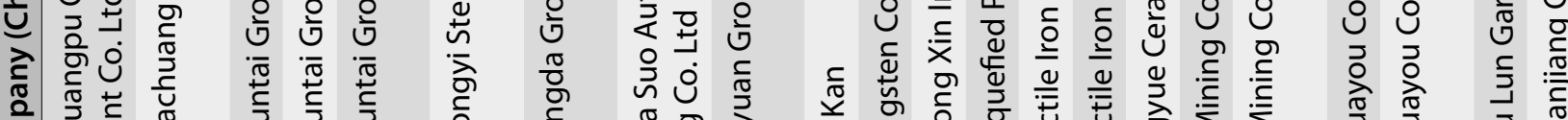

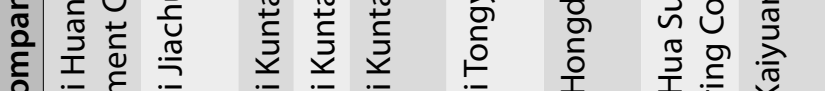

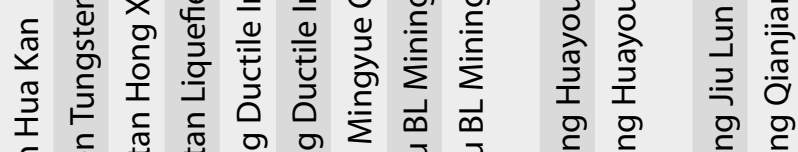

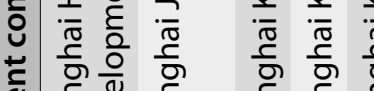

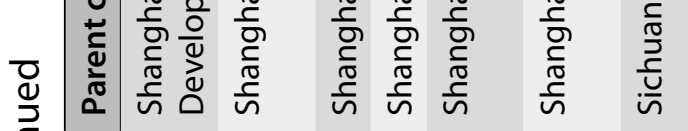

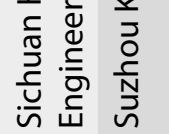

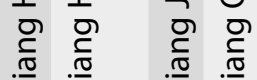

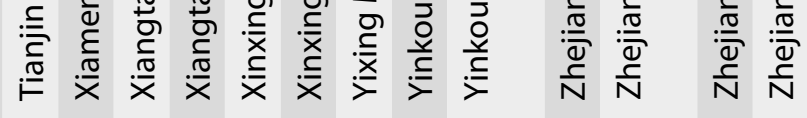

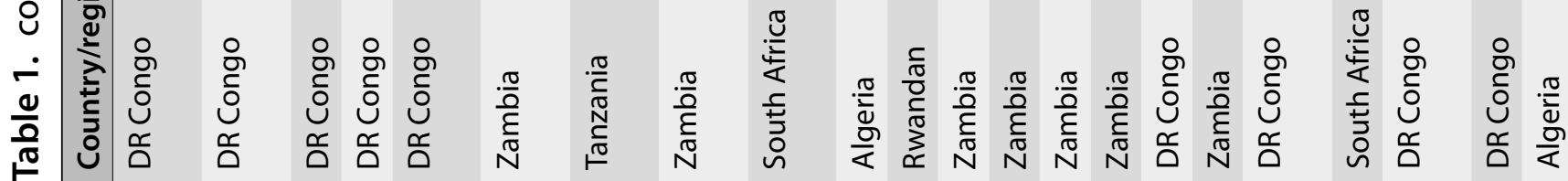




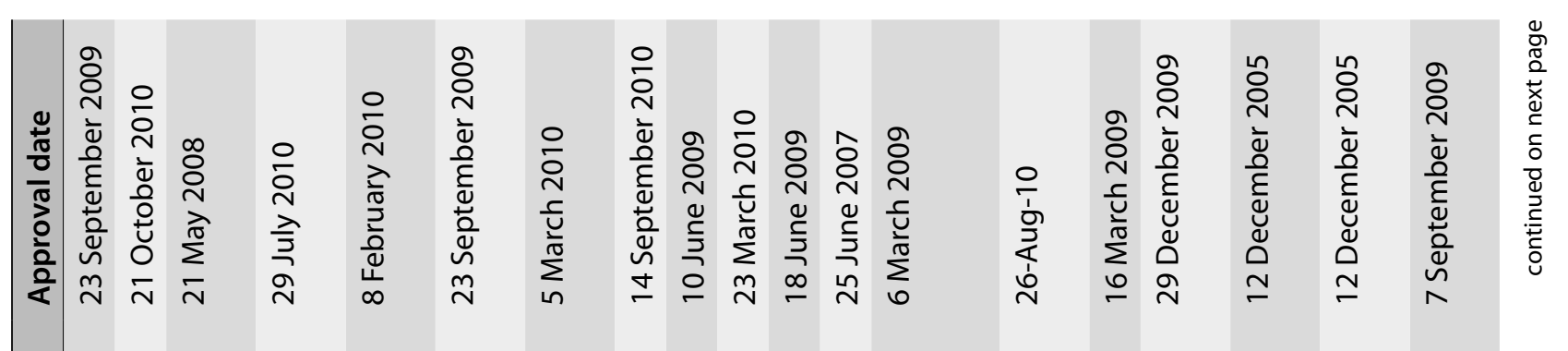

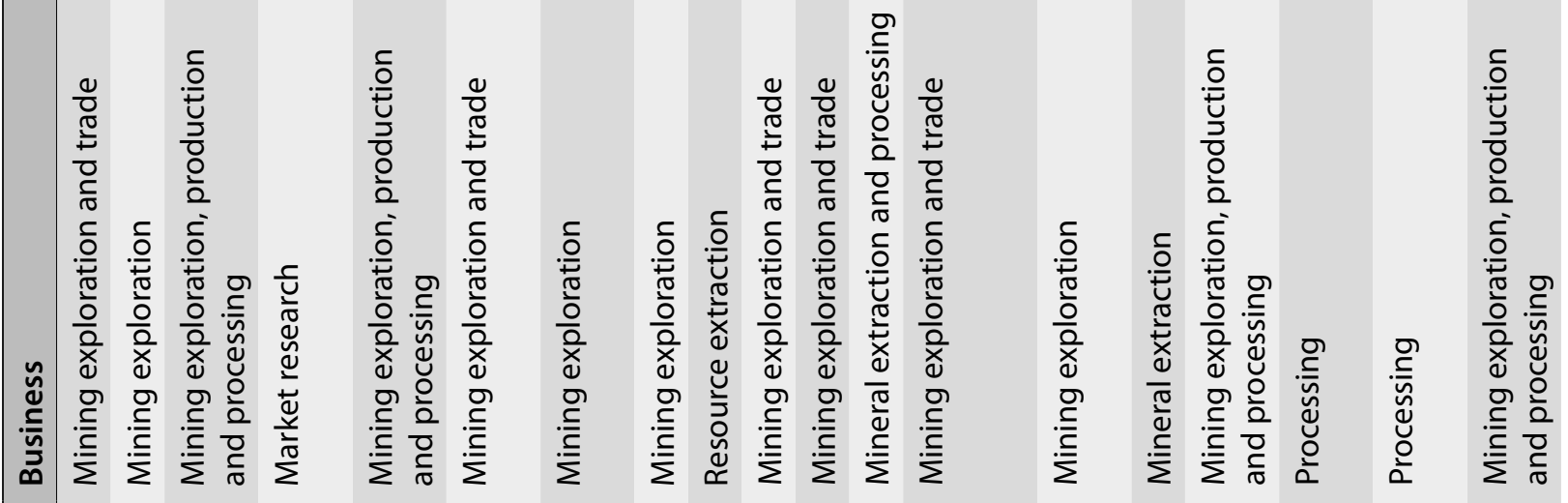

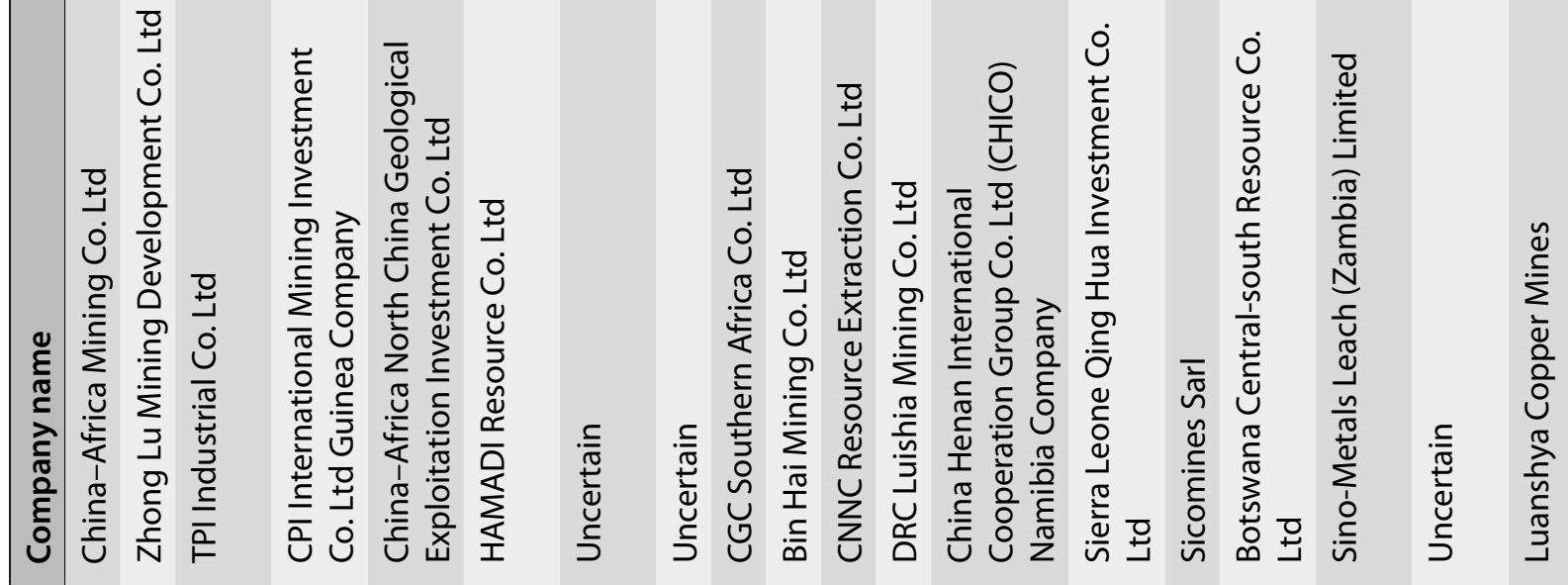

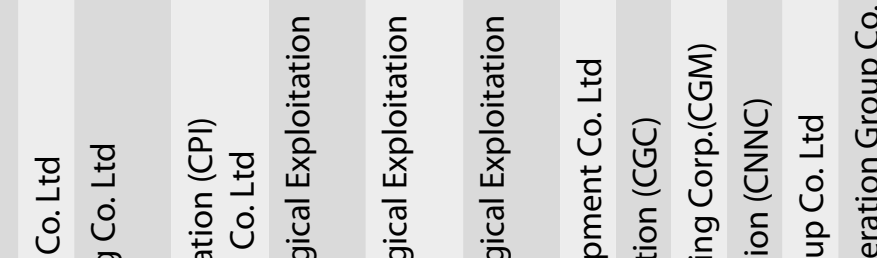

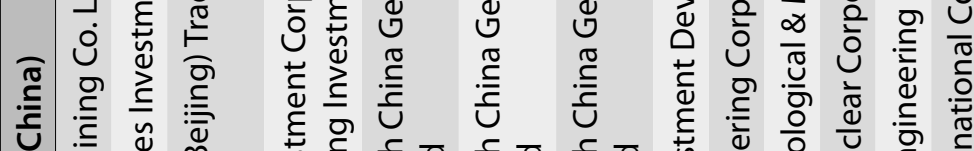

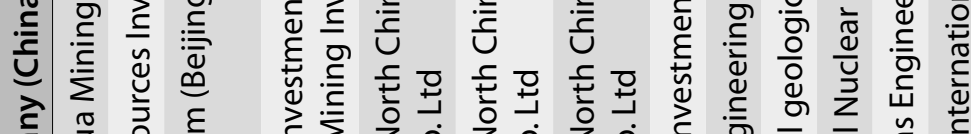

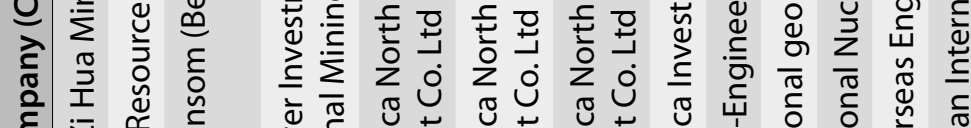

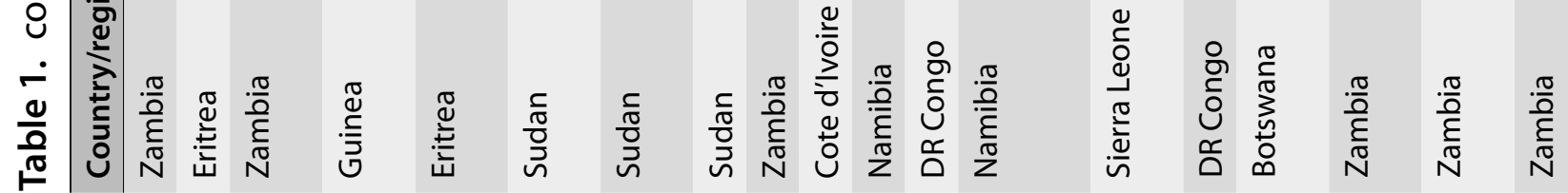




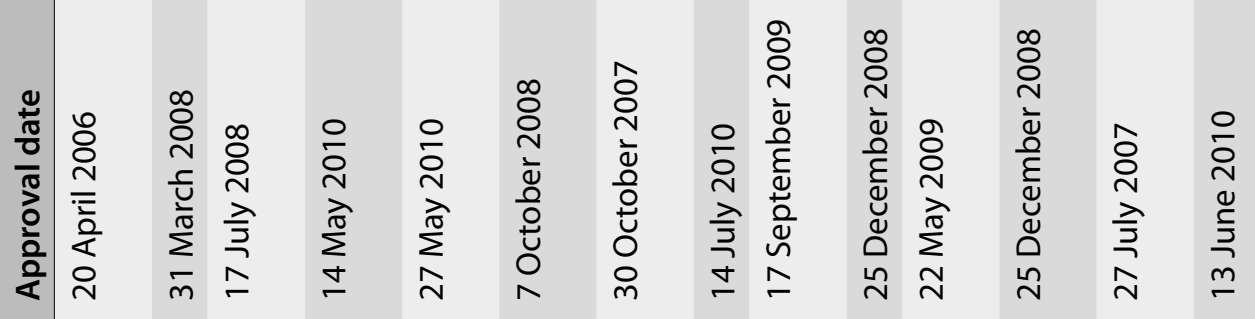

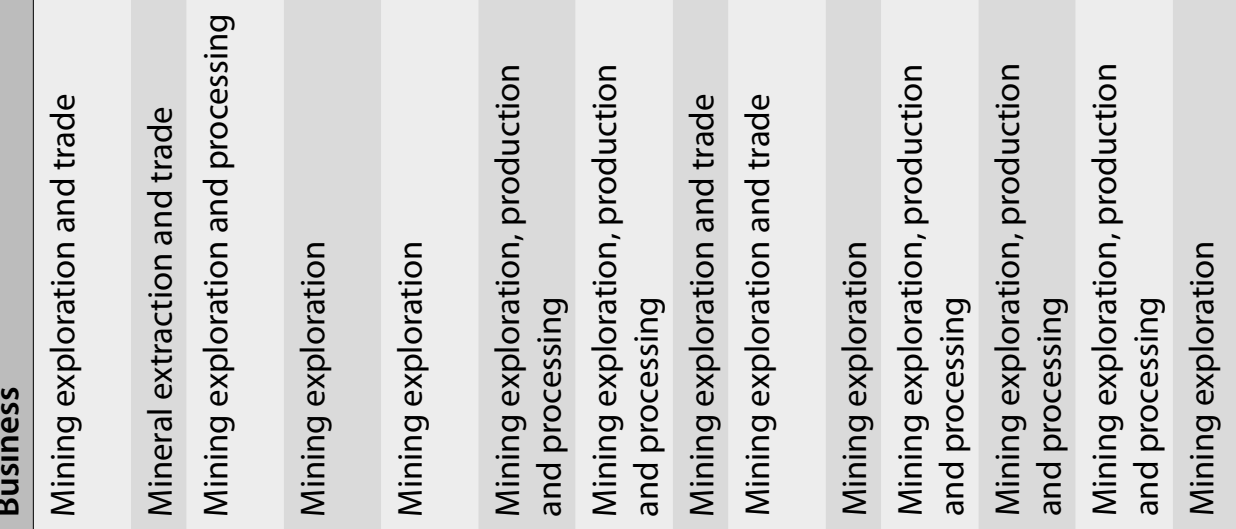
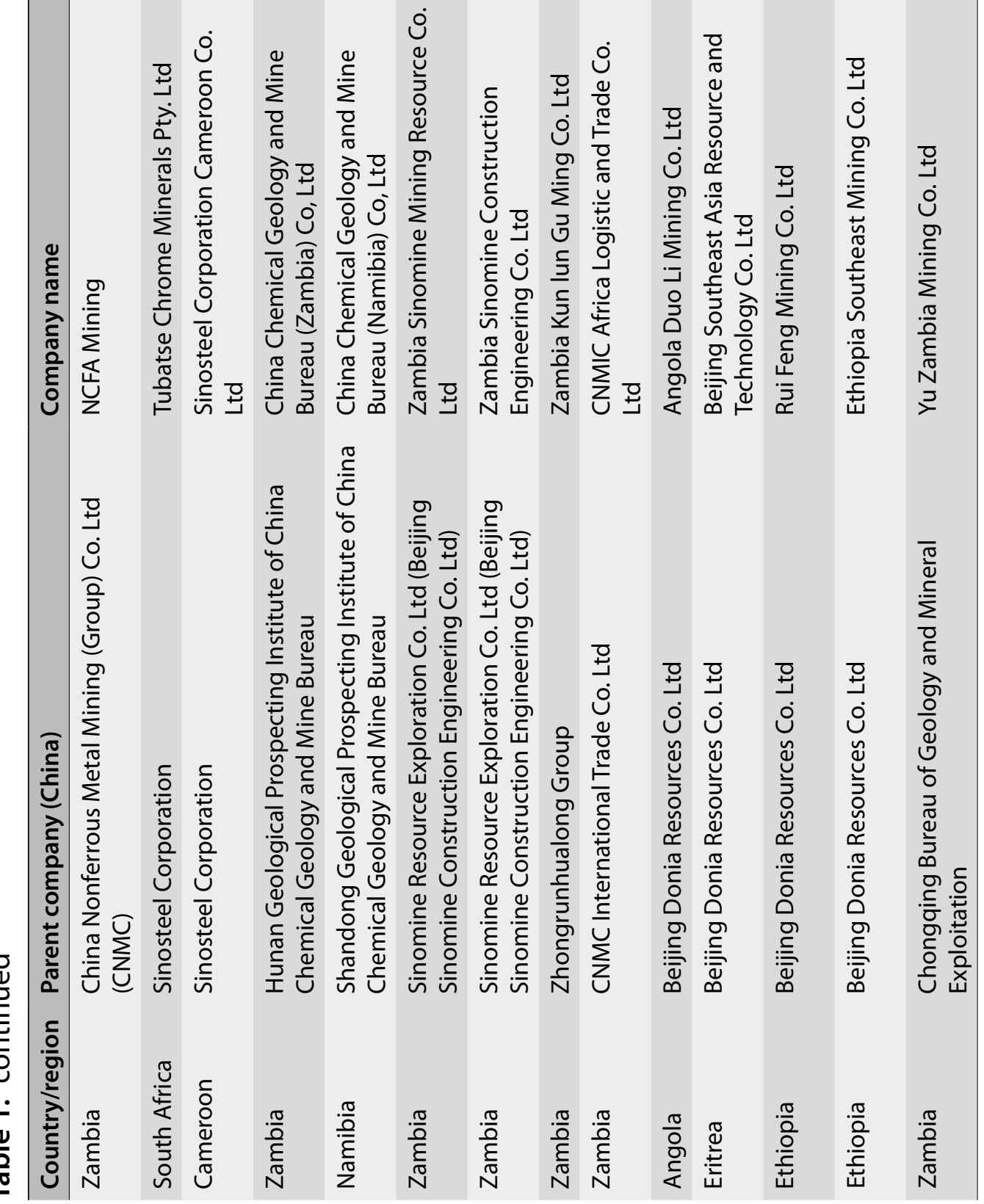


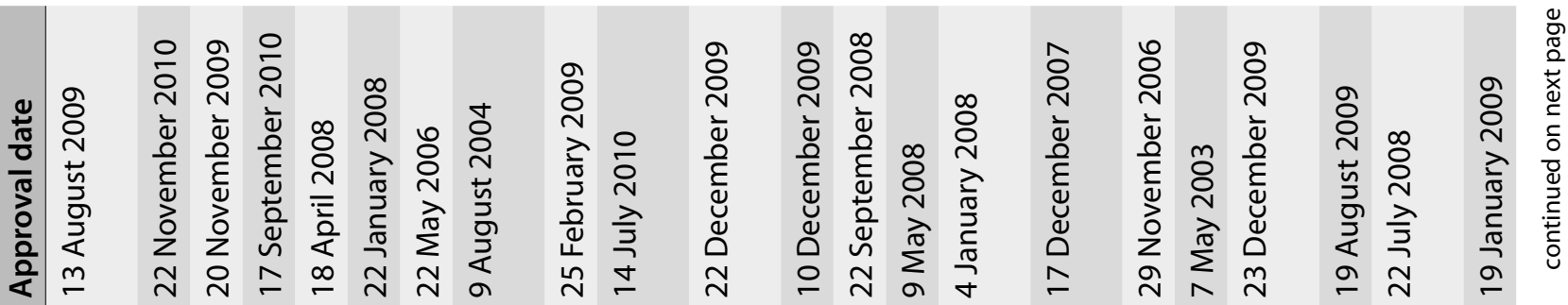

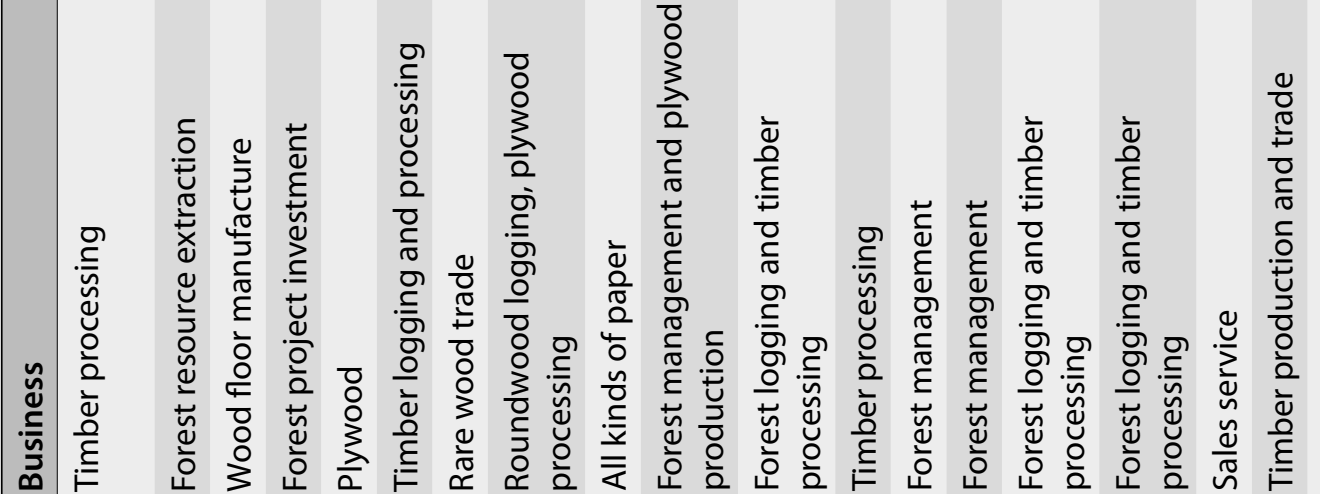

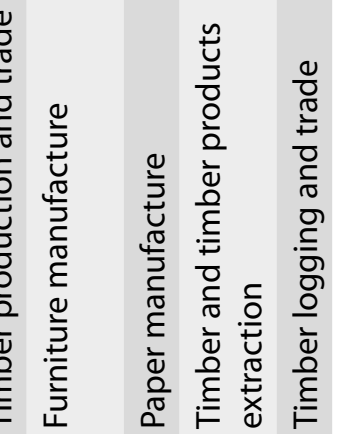

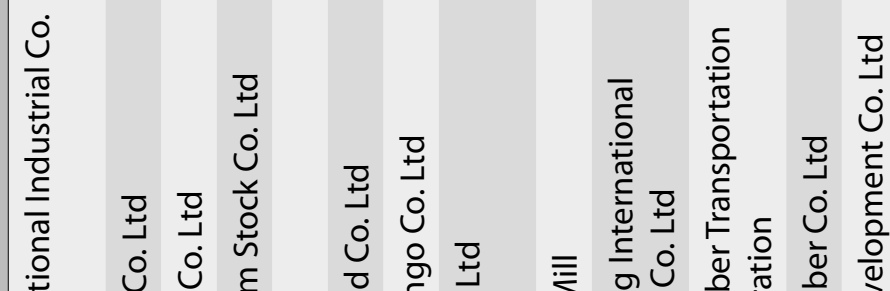

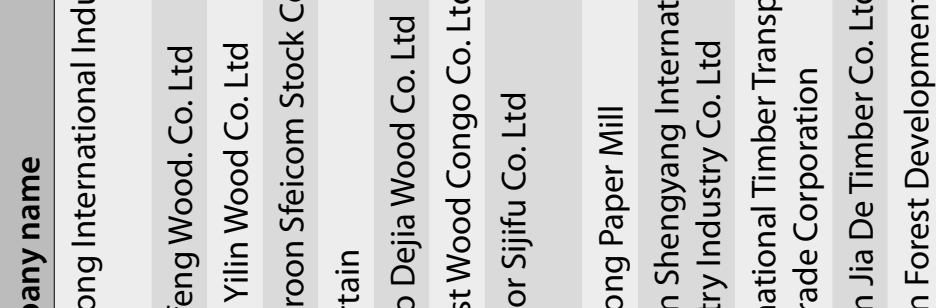

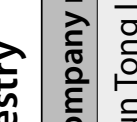

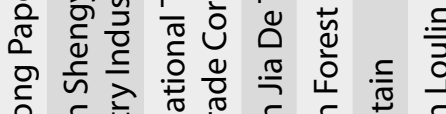

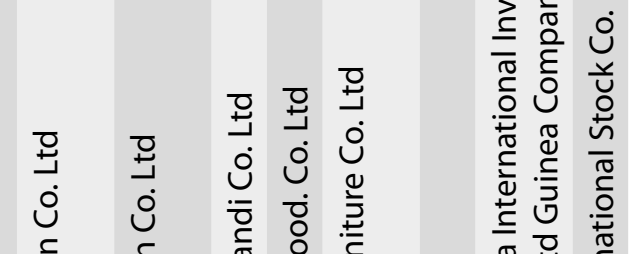

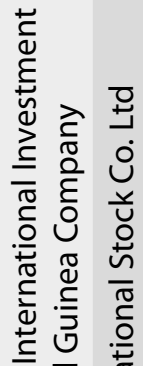

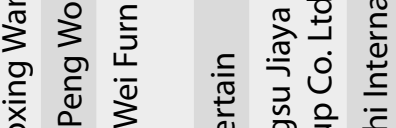

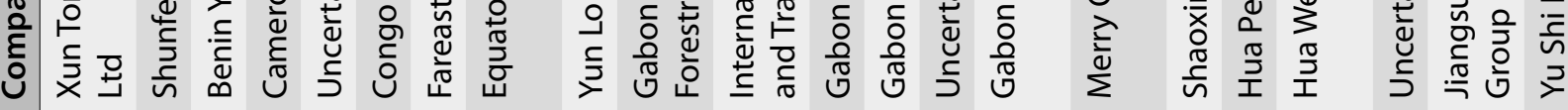

荌
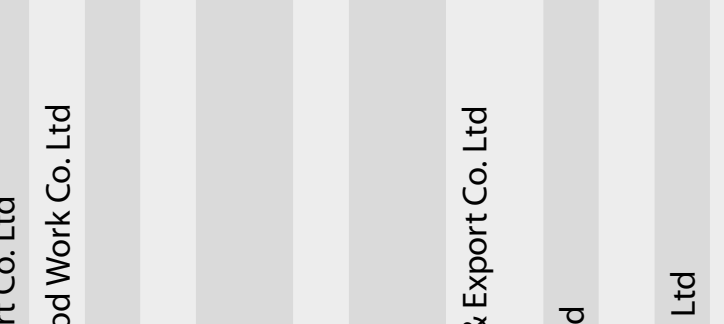

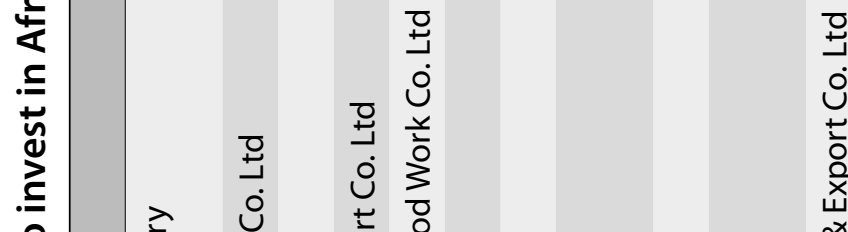

품

ن

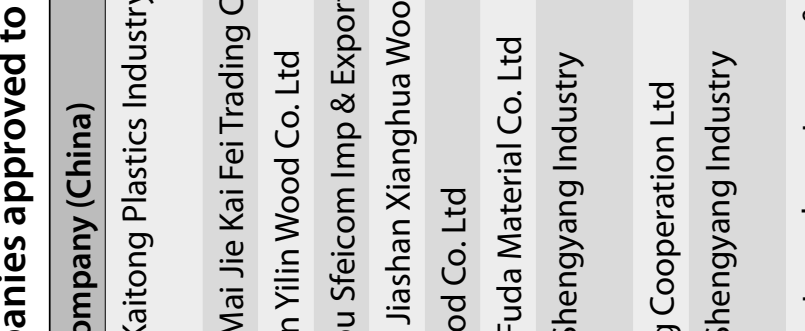




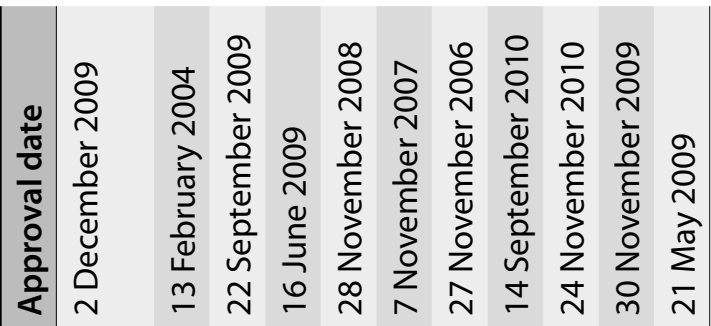
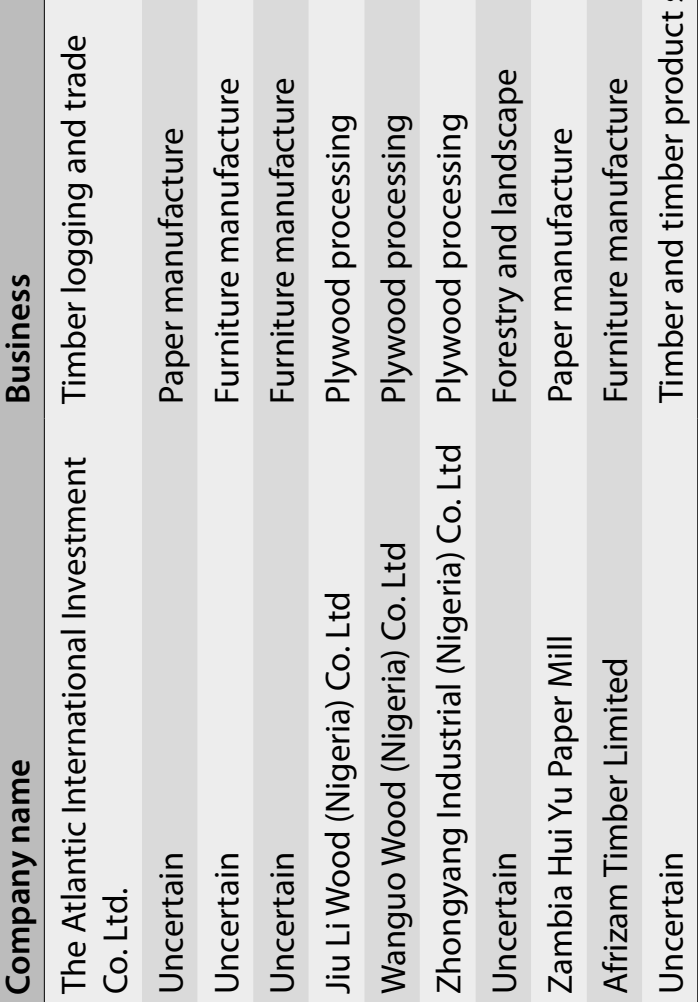

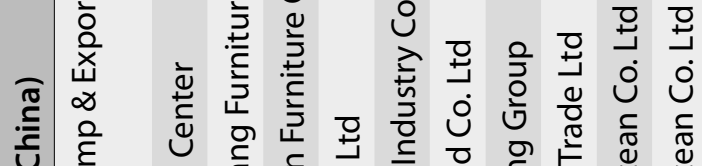

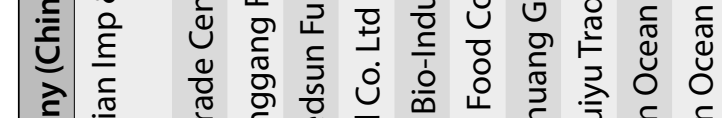

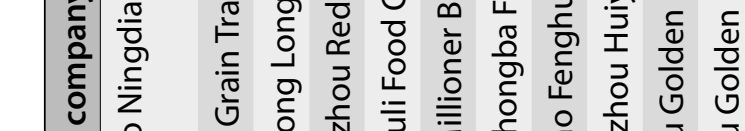

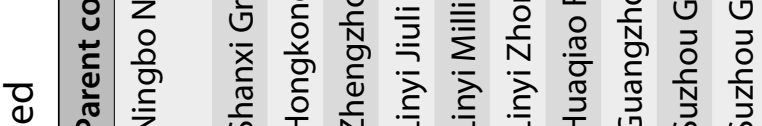

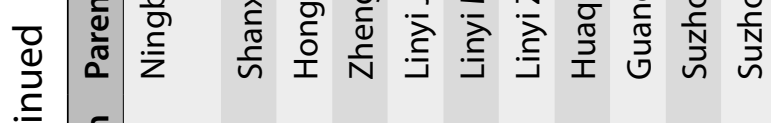

营

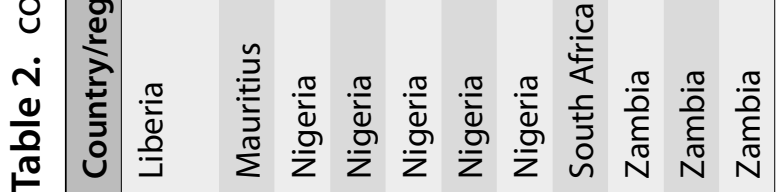




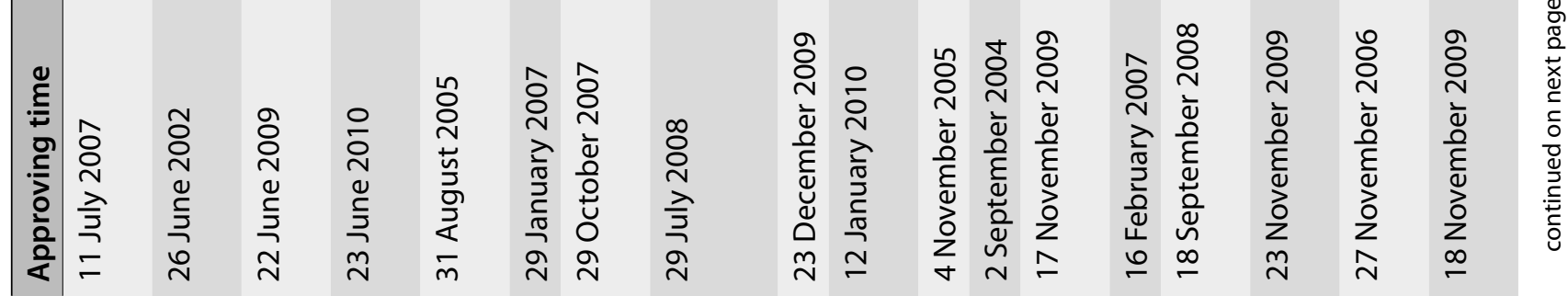

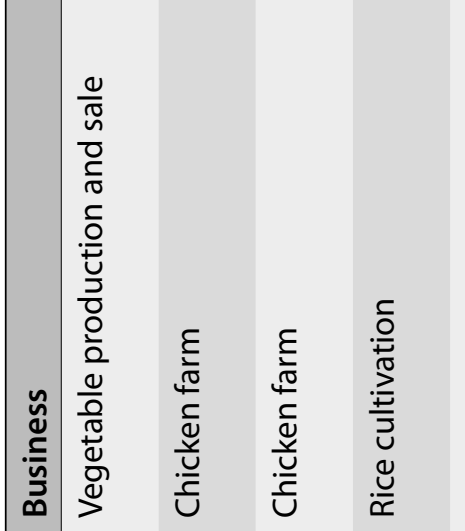

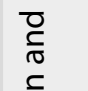

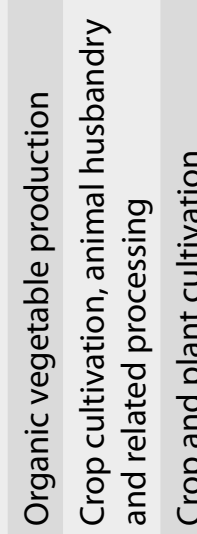

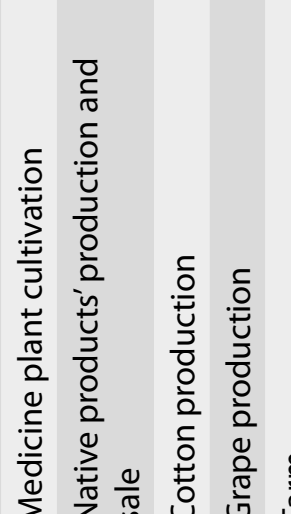

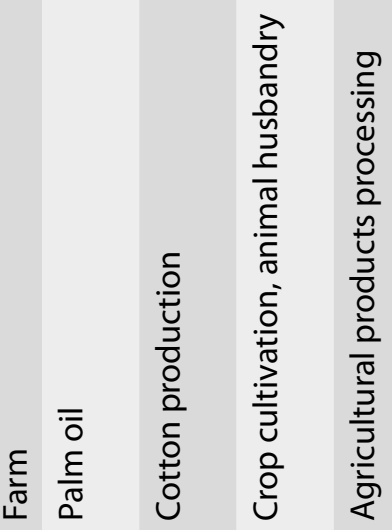

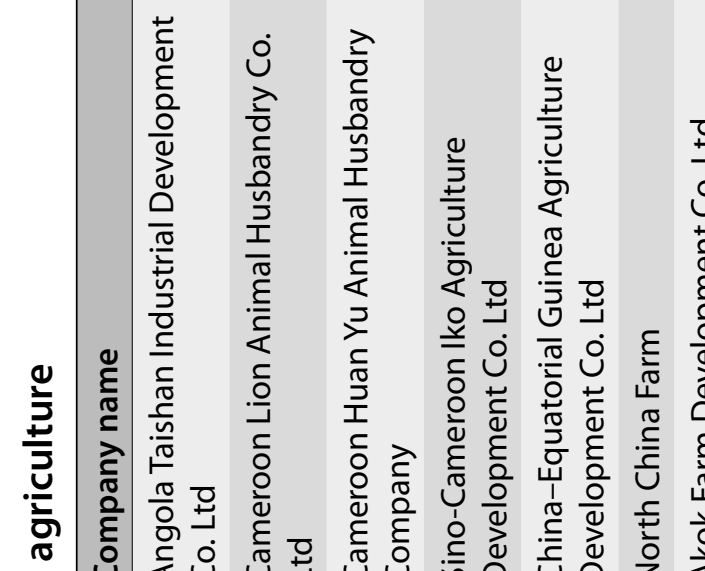<smiles>C=C(C)SC</smiles>

이요

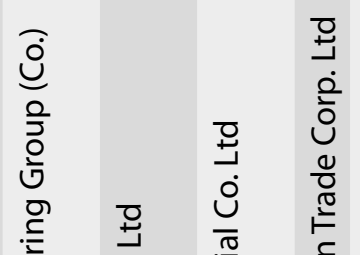

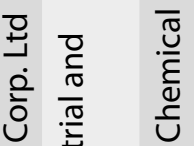

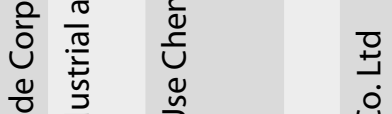

ชั

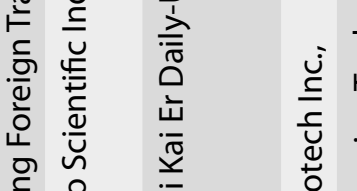

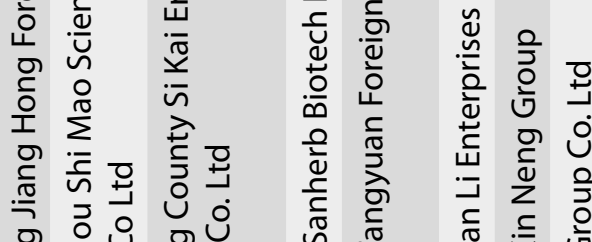

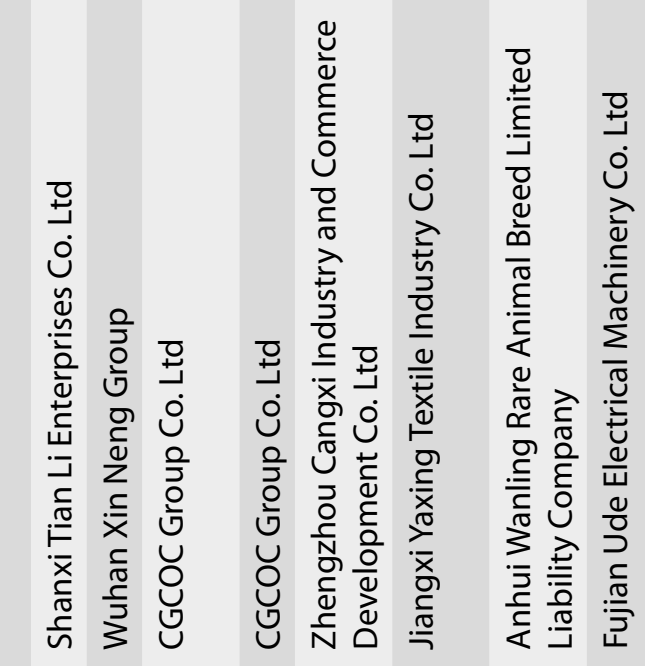

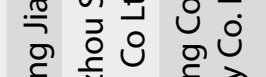

กั ヘิ

㐫

离

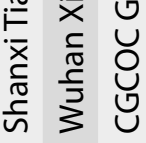




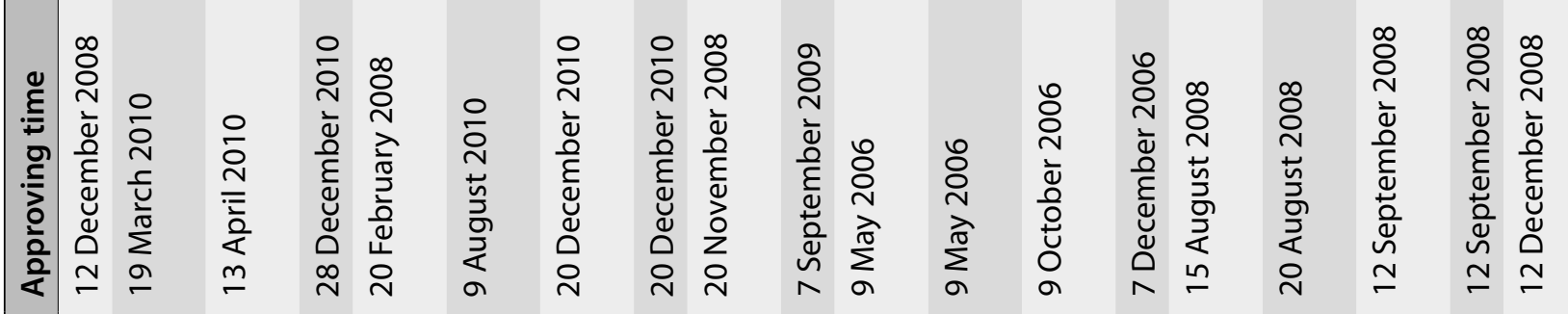

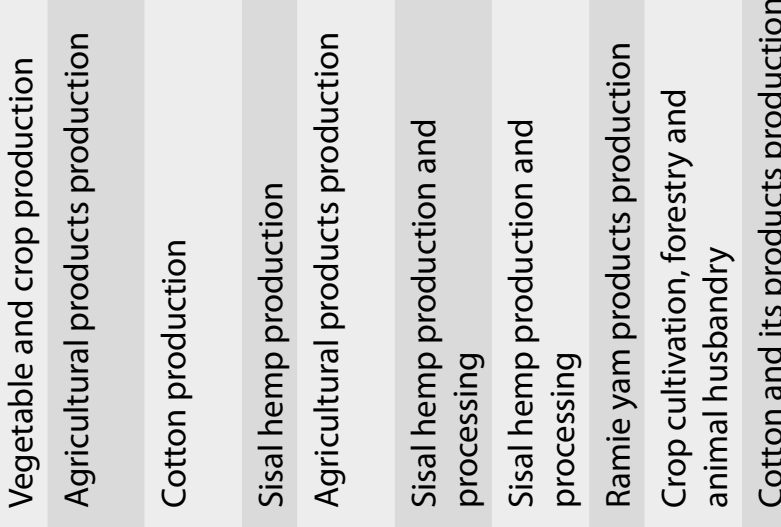

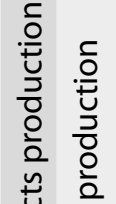

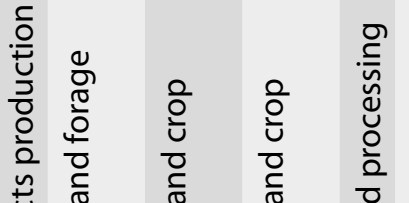

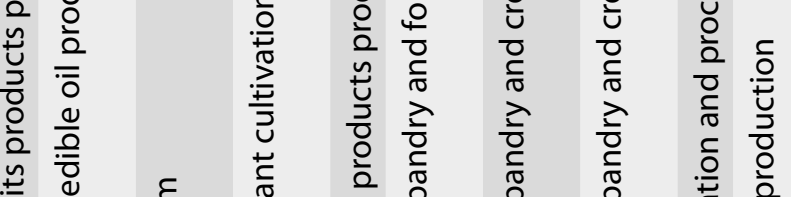

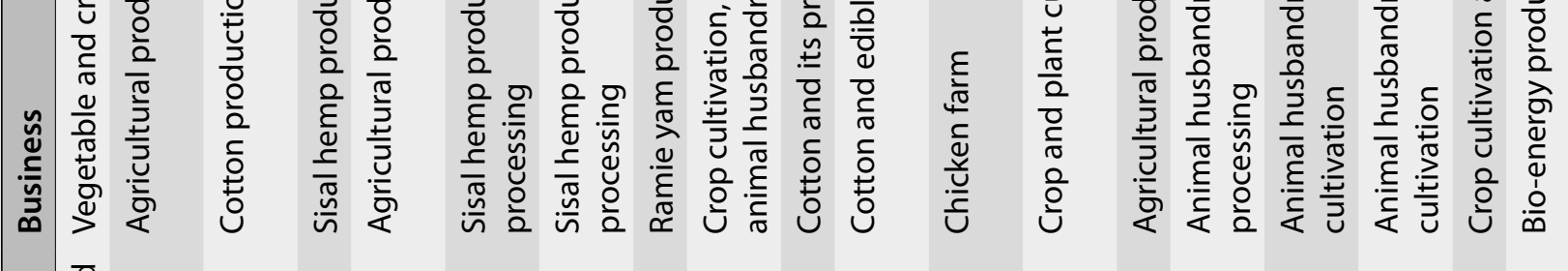

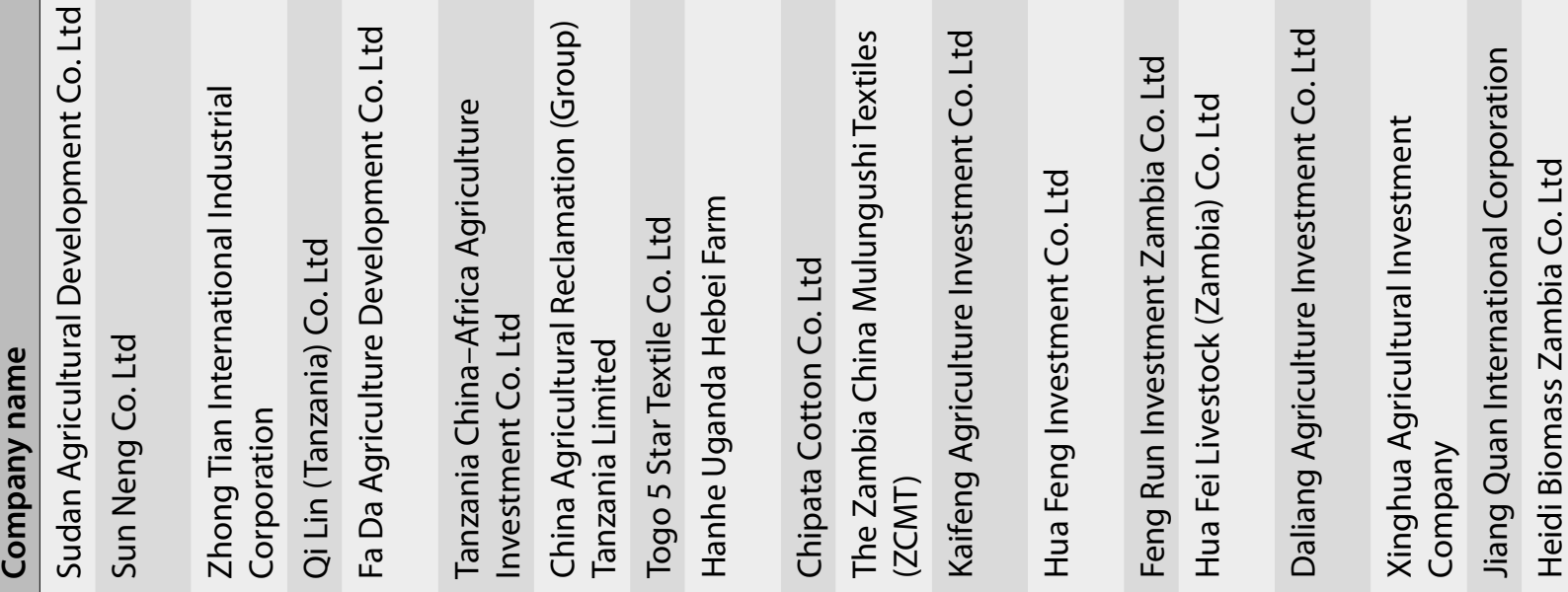

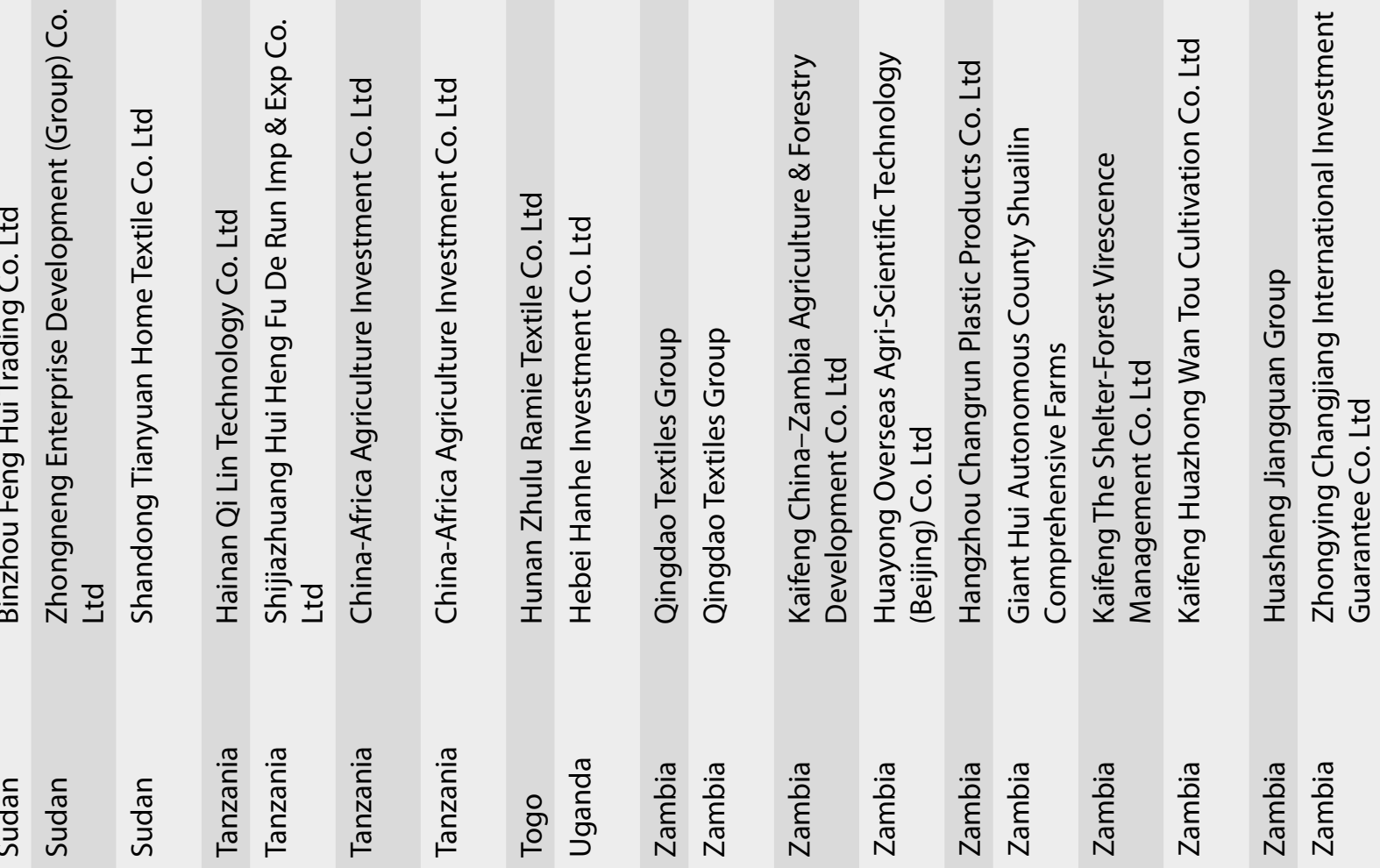




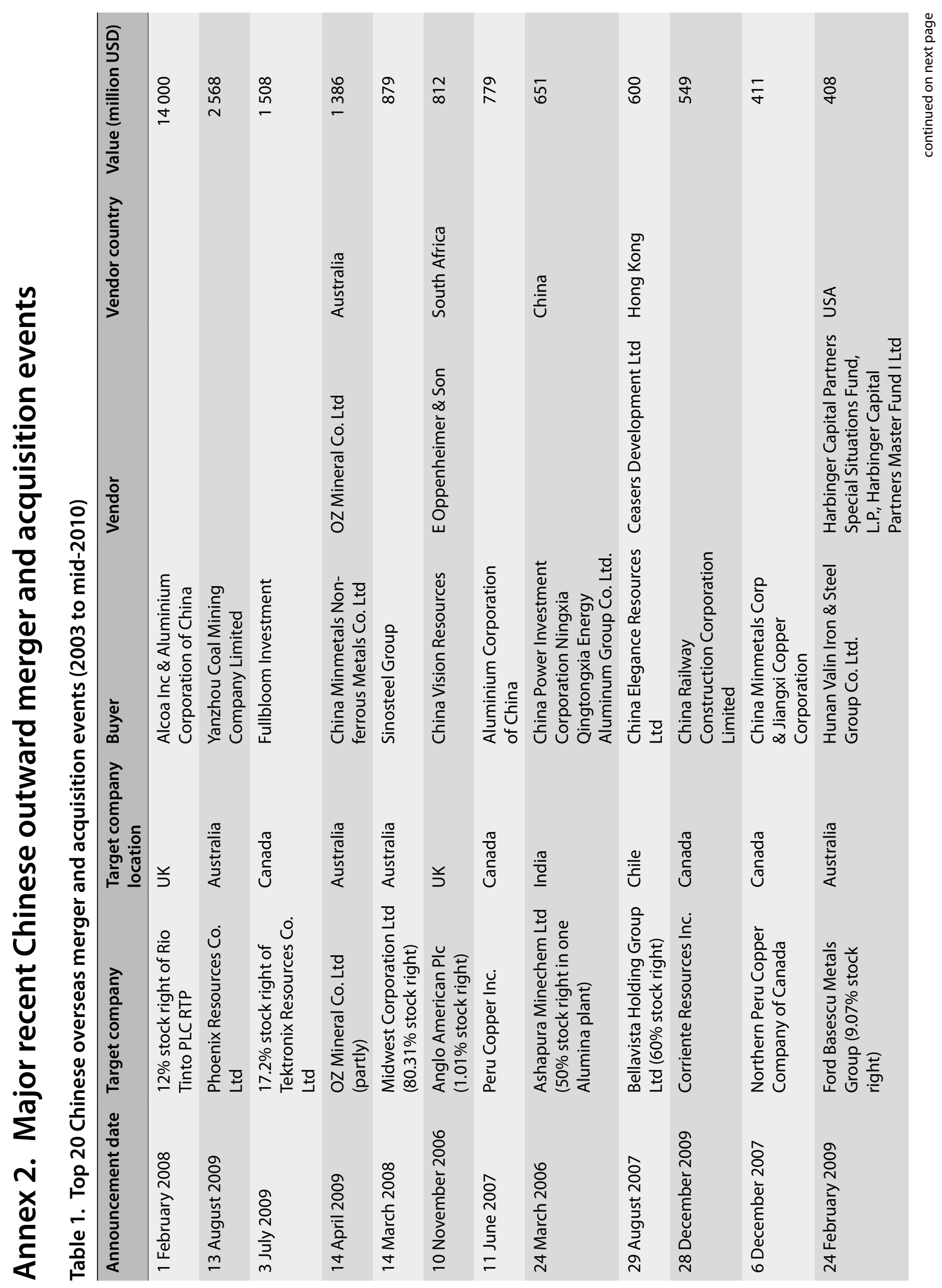




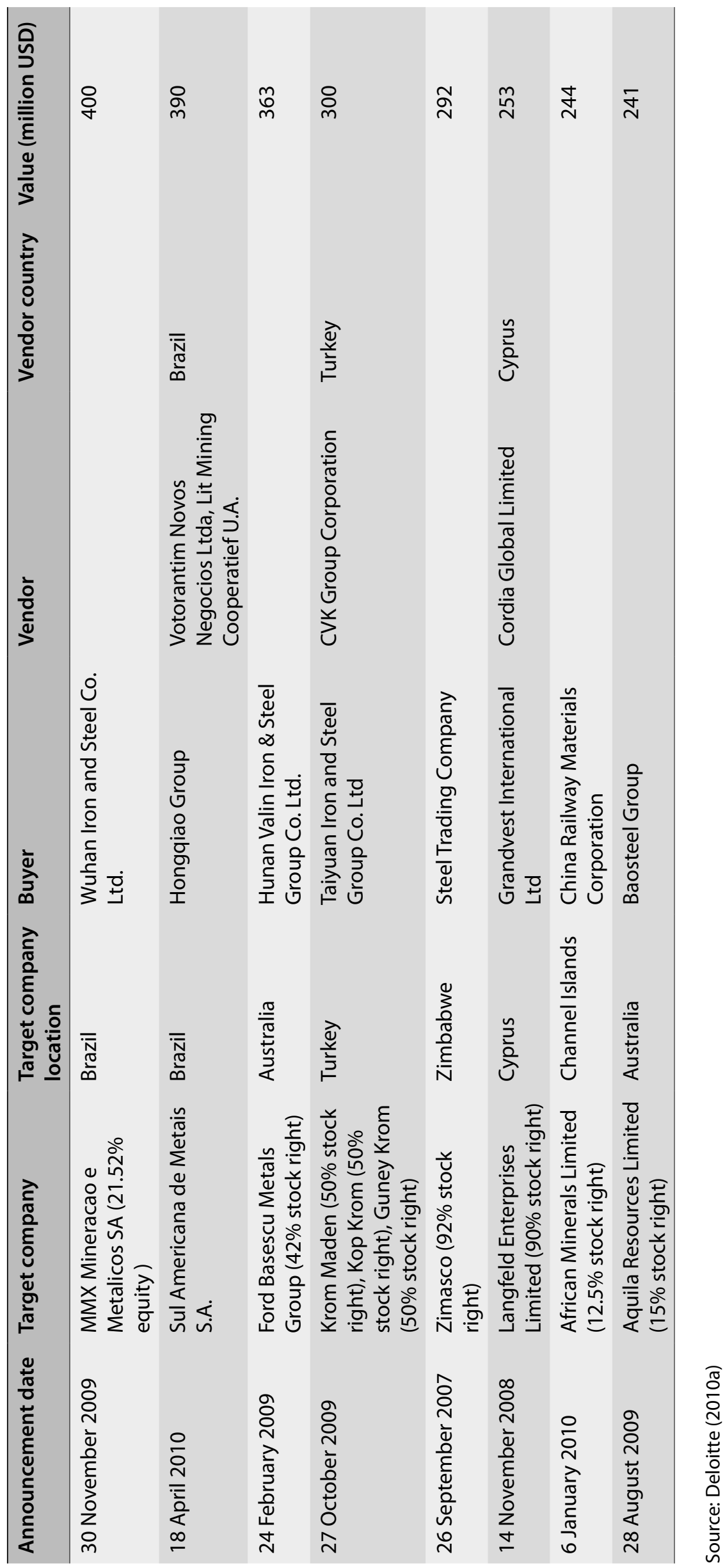




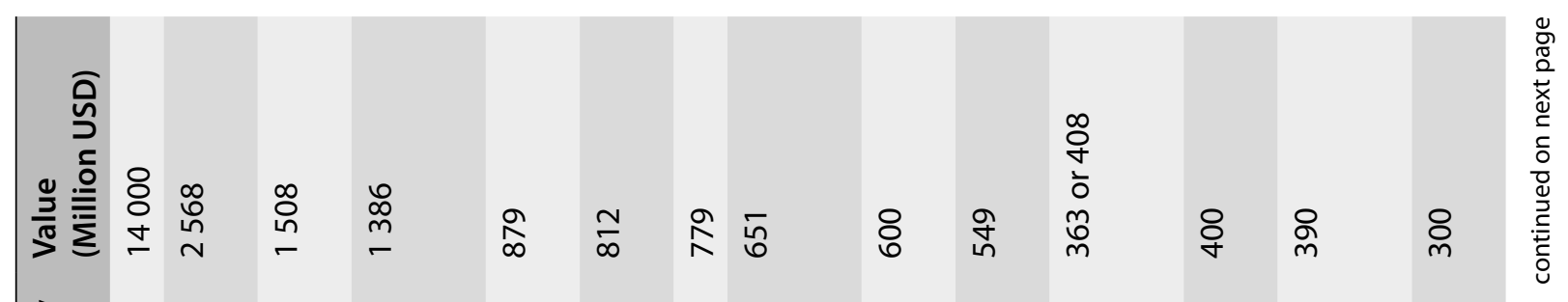

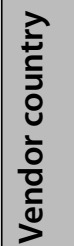

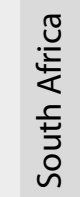

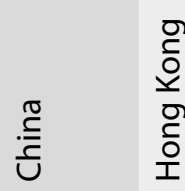

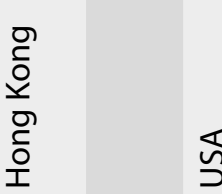

毫

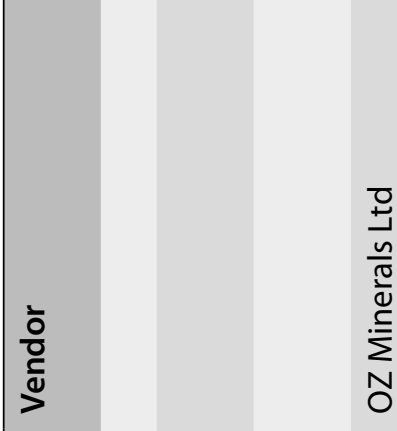

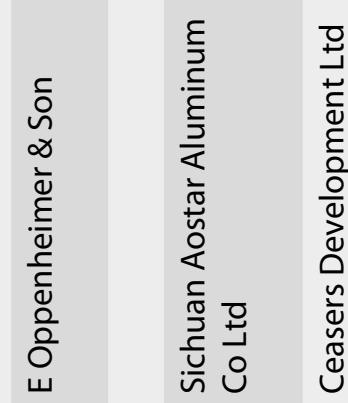

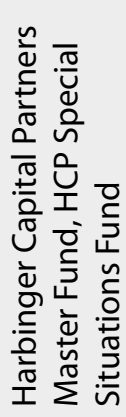

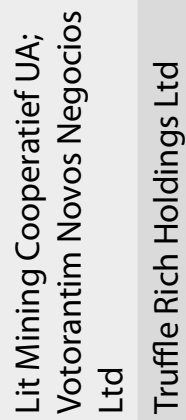

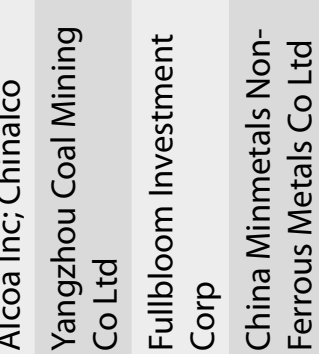

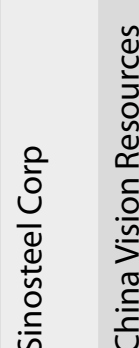

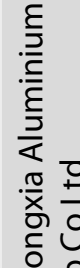

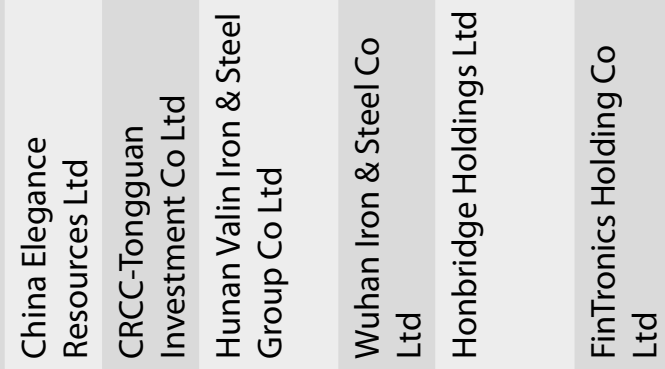

䆣

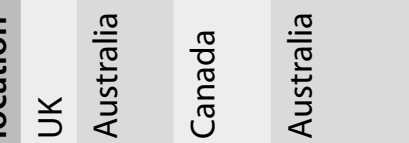

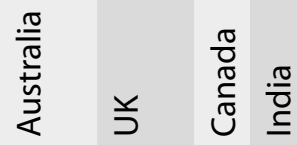

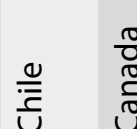

$\frac{\frac{\pi}{\frac{\pi}{0}}}{\frac{\pi}{\frac{n}{2}}}$

$\begin{array}{ll}\bar{N} & \bar{N} \\ \frac{0}{0} & \frac{0}{0}\end{array}$

$\frac{\pi}{\sqrt[n]{n}}$

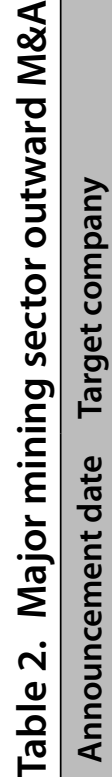

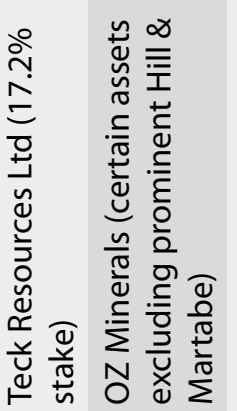

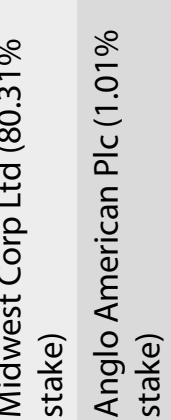

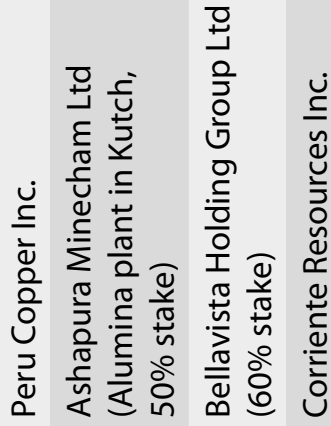

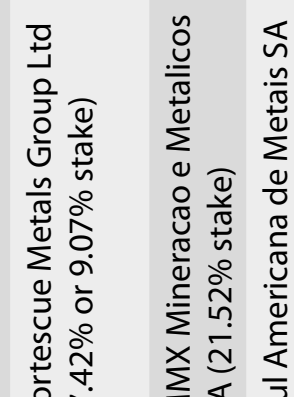

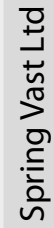

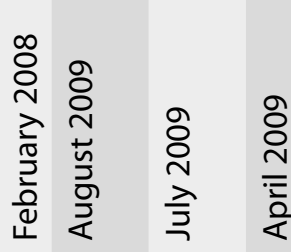

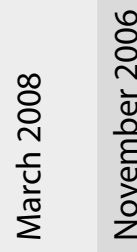

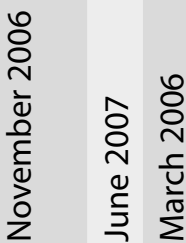
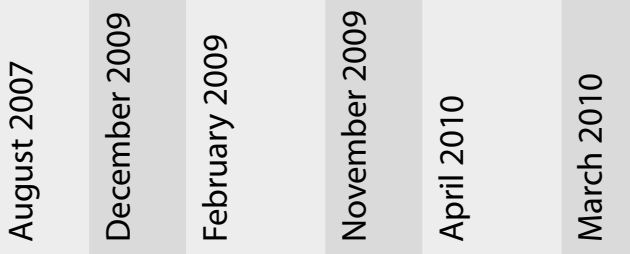


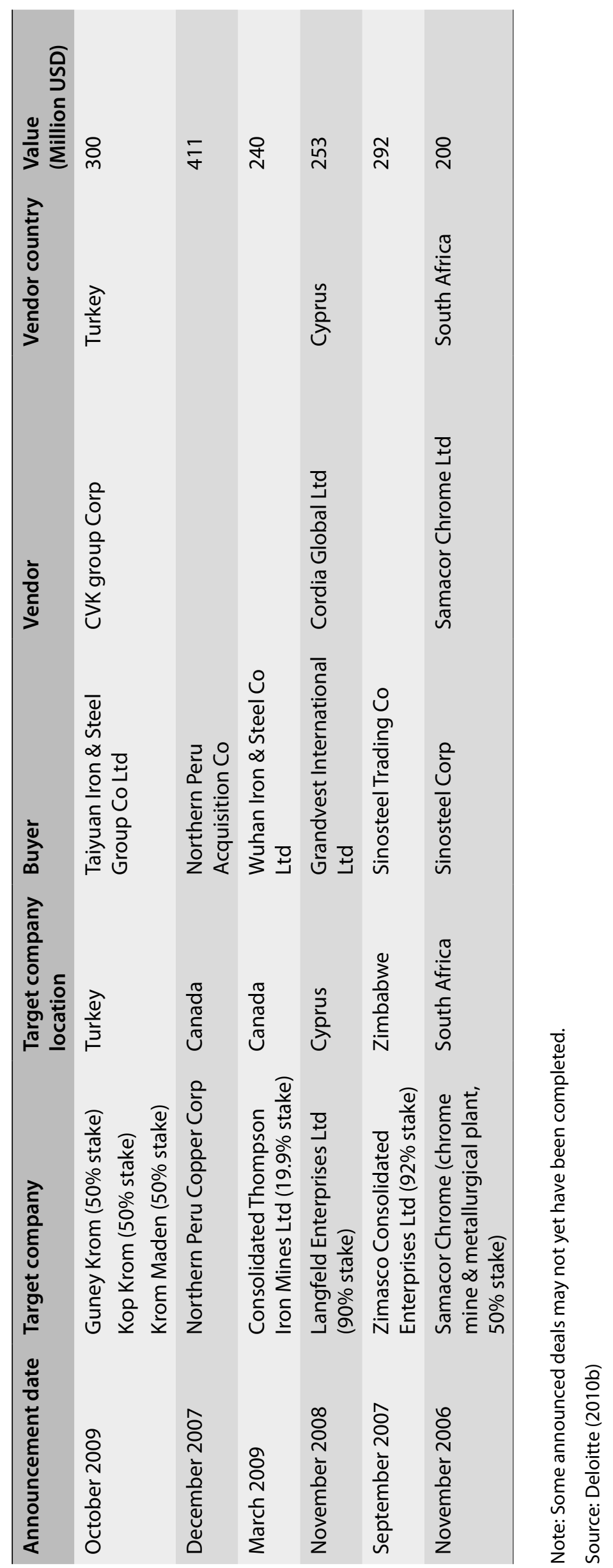



The impacts of Chinese investment in and trade with Africa have become the subject of much speculation. CIFOR's 'Chinese trade and investment in Africa' project seeks to understand the impacts of China's role in shifting global trade flows and investment patterns on forests in two African ecological regions, the Congo Basin and the southern African woodlands, with a focus on sectors with potential direct impacts on forests: mining, forestry and agriculture.

Globally, mergers and acquisitions (M\&A) by Chinese companies have been increasing in recent years. Africa is the second most frequent destination for mining M\&A events, and research shows increased interest in M\&A activity in Africa. Most M\&A activity is in the oil and mining sectors.

Further research is required to produce a comprehensive database of actual Chinese investment activities in Africa. M\&A as a growing form of overseas investment by Chinese companies also merits investigation. 